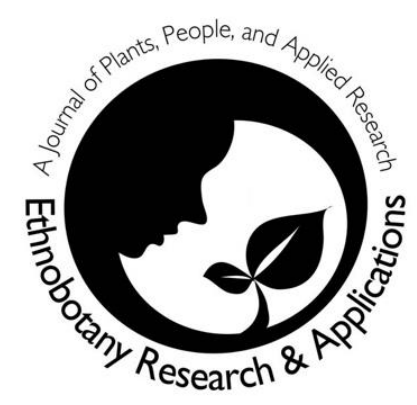

\title{
Medicinal practices of sacred natural sites: a socio-religious approach for successful implementation of primary healthcare services
}

\author{
Rajasri Ray and Avik Ray
}

\section{Review}

\begin{abstract}
Background: Sacred groves are model systems that have the potential to contribute to rural healthcare owing to their medicinal floral diversity and strong social acceptance.
\end{abstract}

Methods: We examined this idea employing ethnomedicinal plants and their application documented from sacred groves across India. A total of 65 published documents were shortlisted for the preparation of database and statistical analysis. Standard ethnobotanical indices and mapping were used to capture the current trend.

Results: A total of 1247 species from 152 families has been documented for use against eighteen categories of diseases common in tropical and subtropical landscapes. Though the reported species are clustered around a few widely distributed families, $71 \%$ of them are uniquely represented from any single biogeographic region. The use of multiple species in treating an ailment, high use value of the popular plants, and cross-community similarity in disease treatment reflects rich community wisdom to explore and apply available natural resources.

Conclusions: Building on the findings, integration of the tradition in primary healthcare policy especially in AYUSH (Ayurveda, Yoga, Naturopathy, Unani, Siddha and Homoeopathy) program has been recommended. This would embrace folk medicinal practices along with sustainable utilization of plant genetic resources in rapidly changing rural landscapes.

\author{
Correspondence \\ Rajasri Ray*, Avik Ray \\ Centre for studies in Ethnobiology, Biodiversity and \\ Sustainability (CEiBa), Malda - 732103, West \\ Bengal, India \\ "Corresponding Author: Rajasri Ray; \\ rajasri@ceibatrust.org \\ Ethnobotany Research \& Applications \\ 20:34 (2020) \\ Key words: AYUSH; Ethnomedicine; Medicinal plant; \\ Sacred grove; Spatial fidelity; Tropical diseases
}

\section{Background}

Human-nature interaction has been long entwined in the history of humanity. Apart from deriving natural resources, humans have a deep rooted tradition of venerating nature which is extensively observed across continents (Verschuuren 2010). The tradition has attracted attention of researchers and policymakers for its impact on local ecological and socioeconomic dynamics. Ethnomedicine that emanated from this tradition, deals health issues with naturederived resources. It offers invaluable benefits to a large section of indigenous, remotely placed, and economically downtrodden people. The age-old system is deeply embedded in local traditions due to strong belief system, time-tested experience, inexpensive, and easily available raw materials; these essentially underlie their high sociocultural acceptance (Currie et al. 2018, Ogundele 2007, Pedersen and Baruffati 1985, Rai \& Lalramnghinglova 2011, Zank \& Hanazaki 2017). Although forests are key resource for medicinal plants (Bhattacharyya et al. 2009, Voeks 1996), the role of culturally protected patches or sacred groves 
cannot be underestimated. Sacred groves are part of forests or forest patches protected by religiouscultural beliefs of local communities. They play an active role in providing critical ecosystem services such as water conservation, soil fertility, species conservation, medicinal plants etc. (Blicharska et al. 2013, Ray et al. 2014).

The grove-based medicinal practices reserve a great potential in primary healthcare improvement especially in rural contexts. It is crucial since successful implementation of primary healthcare program at grass-root level is a serious challenge for many developing and under-developed countries (Hollard \& Sene 2016, Hone et al. 2018, Pandve \& Pandve 2013). The mainstream biomedicinal healthcare often fails to reach geographically isolated and marginalized people despite a plethora of initiatives at national and international levels (e.g., National Health Program in India, Bangladesh, Sri Lanka and African countries, Alma-Ata declaration 1978). In India, several health missions have been introduced at different administrative levels to include people under the national health program. However, the strategy has been re-framed in recent years to make it more inclusive accepting alternative systems of medicine (i.e., codified traditional medicine) (Katoch et al. 2017, Rudra et al. 2017, Samal 2015) because of the prevalence of plurality in healthcare practices (Anonymous 2017, Minocha 1980, Sheehan 2009).

Traditional medicine, be it codified (e.g., Ayurveda, Unani, Siddha) or not (e.g., ethnomedicine) has a strong support base among rural and indigenous societies due to cost effectiveness, success rate, availability, and social compatibility. Ethnomedicine, compared to codified medical system, is relatively widespread and culturally embedded in the communities who are remotely located and predominantly dependent on natural resources (Albert \& Porter 2015, Albert et al. 2015). Largely owing to the informal status of its treatment procedure and knowledge transmission, it has not been formally recognized as a part of the alternative healthcare system at government level, but the documentation is in full swing across the country. Maintaining this connection, sacred groves, tend to play a pivotal role in rural healthcare system (Anyinam 1999, Innocent 2016, Unnikrishnnan 2010, Young 1983).

In India, studies on medicinal plants from sacred groves emphasize on plant diversity and use, application procedure, and an infrequent quantitative estimation of reliability and consensus of plant use (Khumbongmayum et al. 2005, Venkatesh \& Mahammad 2015). Albeit local in character, the volume of documentation clearly indicates its widespread acceptance, capacity in local resource management, and beliefs of local communities. However, there is a conspicuous lack in the countrywide assessment of resource diversity, cross-cultural practices, possibilities of knowledge sharing, uniqueness in plant use and diseases, etc (see Jain 2004 for ethnomedicinal perspective only) which impedes exploration and tapping of unrealized potential of sacred groves in rural health-care. In this backdrop, we sought answers to the following questions 1) how diverse are the medicinal plant resources in the sacred groves and their distribution pattern, 2) what are the prevalent diseases treated currently and remedial measures and 3) possibilities to identify few hotspots with greater assemblage of frequently used species to link them with rural healthcare network. The answers would not only enable generation of a primary level information pool to reinforce grove based healthcare, but can also be invoked in policy and execution.

\section{Methods \\ Data Collection}

Our dataset was built using available information extracted from the published studies. The primary criterion was to capture indigenous medicinal knowledge associated with the sacred groves. Here the term 'indigenous medicinal knowledge' means the use of medicinal plants by indigenous communities and are commonly known as 'ethnomedicine', 'folk medicine' or 'local health tradition (LHT)' (Holley \& Cherla 1998, Mishra et al. 2018). The objective was to analyze ethnomedicinal information from the sacred groves, therefore reports on Ayurvedic usage of plants (even from sacred groves) have been objectively excluded. We have collected information on medicinal plants availability, their usage, plant parts use, and geographic location. Our search activities comprised internet-based search engines (Google, Web of Science), databases on scientific literature (e.g., Science Direct, Scopus), and international and national level ecology and conservation journals using keywords such as 'medicinal plants sacred grove', 'ethnomedicine India', "sacred medicinal plants", "Maharashtra sacred grove medicinal plants" and similar searches with other states, "traditional medicine sacred site". The second major criterion was to ensure a fair coverage of geographic expanse of the country and we were able to accumulate information from 18 out of 28 states and 9 union territories. Our primary search returned a total of 104 documents but many were discarded owing to a mention of ayurvedic usage and inadequate information, so the final list consisted of 65 studies (Table 1). 
Table 1. Studies used for the analysis

\begin{tabular}{|c|c|c|c|}
\hline S.No. & Title & Author & $\begin{array}{l}\text { Journal/Thesis/Project } \\
\text { Report }\end{array}$ \\
\hline 1 & $\begin{array}{l}\text { Sacred plants and their Ethno-botanical } \\
\text { importance in central } \\
\text { India: A mini review }\end{array}$ & Sahu et al. (2013) & $\begin{array}{l}\text { International Journal of } \\
\text { Pharmacy \& Life Science, 4(8): } \\
2910-2914\end{array}$ \\
\hline 2 & $\begin{array}{l}\text { Assessment of status and role of sacred groves } \\
\text { in conservation of biodiversity at different levels } \\
\text { in Madhya Pradesh }\end{array}$ & $\begin{array}{l}\text { Shrivastava and } \\
\text { Masih (2008-09) }\end{array}$ & Project report \\
\hline 3 & $\begin{array}{l}\text { Role of Sacred Plants in Religion and Health- } \\
\text { care system of local people of Almora district of } \\
\text { Uttarakhand State (India) }\end{array}$ & $\begin{array}{l}\text { Sharma and Joshi } \\
(2010)\end{array}$ & Academia Arena, 2(6): 19-22 \\
\hline 4 & $\begin{array}{l}\text { Biodiversity conservation through a traditional } \\
\text { beliefs system : a case study from Kumaon } \\
\text { Himalaya, India }\end{array}$ & Singh et al.(2012) & $\begin{array}{l}\text { International Journal of } \\
\text { Conservation Science, 3(1):33- } \\
40\end{array}$ \\
\hline 5 & $\begin{array}{l}\text { An ethnobotanical study of medicinal plants } \\
\text { used in sacred groves of Kumaon } \\
\text { Himalaya,Uttarakhand, India }\end{array}$ & Singh et al. (2014) & $\begin{array}{l}\text { Journal of } \\
\text { Ethnopharmacology, 154:98- } \\
108\end{array}$ \\
\hline 6 & $\begin{array}{l}\text { Sacred Grove in conservation of plant } \\
\text { biodiversity in Mahendergarh district of Haryana }\end{array}$ & Yadav et al. (2010) & $\begin{array}{l}\text { Indian Journal of Traditional } \\
\text { Knowledge, 9(4):693-700 }\end{array}$ \\
\hline 7 & $\begin{array}{l}\text { Local deities in conservation -A conservation } \\
\text { practice in Banju Nami Tok sacred grove in } \\
\text { Tehri Garhwal ,Uttarkhand }\end{array}$ & Pala et al. (2012) & $\begin{array}{l}\text { The Indian Forester, 138(8): } \\
710-713\end{array}$ \\
\hline 8 & $\begin{array}{l}\text { Patalbhuvneshwar: a new sacred grove from } \\
\text { Kumaon Himalaya }\end{array}$ & $\begin{array}{l}\text { Agnihotri et al. } \\
(2012)\end{array}$ & $\begin{array}{l}\text { Current Science, 102(6):830- } \\
831\end{array}$ \\
\hline 9 & $\begin{array}{l}\text { Traditional knowledge and biodiversity } \\
\text { conservation in the sacred groves of Meghalaya }\end{array}$ & Jeeva et al. (2006) & $\begin{array}{l}\text { Indian Journal of Traditional } \\
\text { Knowledge, 5(4) 563-568 }\end{array}$ \\
\hline 10 & $\begin{array}{l}\text { Ethnomedicinal plants in the sacred groves of } \\
\text { Manipur }\end{array}$ & $\begin{array}{l}\text { Khumbongmayum } \\
\text { et al. (2005) }\end{array}$ & $\begin{array}{l}\text { Indian Journal of Traditional } \\
\text { Knowledge, 4(1):21-32 }\end{array}$ \\
\hline 11 & $\begin{array}{l}\text { Distribution and conservation status of sacred } \\
\text { groves (SGs) in Garo Hills, Meghalaya }\end{array}$ & $\begin{array}{l}\text { Mohanta et al. } \\
(2009)\end{array}$ & $\begin{array}{l}\text { The Indian Forester, } \\
\text { 135(12):1627-1649 }\end{array}$ \\
\hline 12 & $\begin{array}{l}\text { Sacred Groves :An analysis made in the cultural } \\
\text { perspective within BTC Assam,India }\end{array}$ & $\begin{array}{l}\text { Brahma et al. } \\
(2014)\end{array}$ & $\begin{array}{l}\text { Journal of Biological \& } \\
\text { Scientific Opinion, 2(5):320- } \\
323\end{array}$ \\
\hline 13 & $\begin{array}{l}\text { Status of medicinal plants in the disturbed and } \\
\text { the undisturbed sacred forests of Meghalaya, } \\
\text { northeast India:population structure and } \\
\text { regeneration efficacy of some important species }\end{array}$ & Laloo et al. (2006) & $\begin{array}{l}\text { Current Science, 90(2):225- } \\
232\end{array}$ \\
\hline 14 & $\begin{array}{l}\text { Geo environmental appraisal of sacred groves } \\
\text { and its releated traditional practices in West } \\
\text { Bengal }\end{array}$ & Pal (2013) & $\begin{array}{l}\text { Ph. D. Thesis. Department of } \\
\text { Geography, Visva-Bharati, } \\
\text { Santiniketan }\end{array}$ \\
\hline 15 & $\begin{array}{l}\text { Role of sacred groves in the conservation and } \\
\text { management of medicinal plants }\end{array}$ & $\begin{array}{l}\text { Behera et al. } \\
(2015)\end{array}$ & $\begin{array}{l}\text { Journal of Medicinal Plants } \\
\text { Research, } 9(29): 792-798\end{array}$ \\
\hline 16 & $\begin{array}{l}\text { Ethnomedicinal plant conservation through } \\
\text { sacred groves }\end{array}$ & $\begin{array}{l}\text { Bhakat and Sen } \\
(2008)\end{array}$ & $\begin{array}{l}\text { Tribes And Tribals, Special } \\
\text { Volume (2):55-58 }\end{array}$ \\
\hline 17 & $\begin{array}{l}\text { Differences in tree species diversity and soil } \\
\text { nutrient status in a tropical sacred forest } \\
\text { Ecosystem on Niyamgiri Hill Range, Eastern } \\
\text { Ghats, India }\end{array}$ & Sahu et al. (2012) & $\begin{array}{l}\text { Journal of Mountain Science, } \\
9: 492-500\end{array}$ \\
\hline 18 & $\begin{array}{l}\text { An ethnobotanical study of medicinal plants } \\
\text { used in sacred groves of Ambaji forest, Gujarat, } \\
\text { India }\end{array}$ & Patel (2015) & $\begin{array}{l}\text { International Journal of } \\
\text { Advanced Technology in } \\
\text { Engineering and Science, } \\
3(1): 285-295\end{array}$ \\
\hline
\end{tabular}


19 Floristic and ethnobotany of sacred groves of Kheda District (Gujarat) and their significance in conserving biodiversity

20 Flora of sacred groves at Sriharikota Island, Andhra Pradesh, India

21 Some ethno medicinal plants of Parnasala sacred grove area Eastern Ghats of Khammam District, Telangana, India

22 Sacred groves of Parinche valley of Pune district of Maharashtra, India and their importance

23 Validation of indigenous knowledge of Yanadi tribe and local villagers of Veyilingalakona- A sacred grove of Andhra Pradesh, India.

24 Studies on the phytodiversity of a sacred grove and its traditional uses in Karaikal District, U.T. Puducherry

25 Role of sacred groves in consevation of ethno medicinal plants in Dapoli tehsil of Ratnagiri district, Maharashtra(India)

26 Medicinal plant resources of Rudrakod sacred grove in Nallamalais, Andhra Pradesh, India

27 Ethno-floristic survey in sacred groves, Pudukottai district, Tamil Nadu- India

28 Floristic composition and practices on the selected sacred groves of Pallapatty village (Reserved forest), Tamil Nadu

29 Studies on the plant diversity of Muniandavar sacred groves of Thiruvaiyaru, Thanjavur, Tamil Nadu, India

30 Phytodiversity of ethnomedicinal plants in sacred groves and its traditional uses in Kabirdham district of Chhattisgarh

31 Studies on the sacred groves of Kannur District

32 Ethnobotanical plants used by the tribes of R.D.F. Poshina forest range of Sabarkantha District, North Gujarat, India

33 Medicinally valuable plants from sacred groves of Jabalpur forest division (Madhya Pradesh)

34 Ethnobotanical studies on Japali Hanuman Theertham- A Sacred Grove of Tirumala hills, Andhra Pradesh, India.

35 Ethno-Medicinal plants in sacred groves in East Godavari District, Andhra Pradesh, India

36 Phytodiversity and conservation of Nithypooja Kona sacred grove of Nallamala Hill Range,Eastern Ghats,Andhra Pradesh

37 Sacred and medicinal plant diversity of Vandiol sacred grove of Sabarkantha District(N.G)

38 Ethnobotanical study of sacred groves of Poshina forest of Sabarkanth district,North Gujarat

39 Role of traditional conservation practice: highlighting the importance of Shivbari sacred grove in biodiversity conservation
Patel (2015)

Hemchandracharya North

Gujrat University,Patan

Kumar (2010)

Rao et al. (2015) Journal of Pharmaceutical

Ethnobotanical Leaflets, $14: 420-426$ Sciences \& Research, 7(4):210-218

Chandrakant et al. Anthropology \& Medicine, (2006)

13(1):55-76

Savithramma et al. Journal of Pharmaceutical (2014)

Sambandan and Dhatchanamoorthy (2012)

Ghalme and

Deokule (2014)

Science \& Research, 6(11):382-388

Journal of Phytology, 492):1621

The Indian Forester, 140(7):701-706

Rao and Sunitha (2011)

Journal of Biodiversity, 2(2):75-89

Anbarashan et al. (2011)

Ganesan et al. (2009)

Jayapal et al. (2014)

Rahangdale et al. (2014)

Journal of Medicinal Plants Research, 5(3):439-443

Indian Journal of Traditional Knowledge, 8(2):154-162

Hygeia journal for drugs and medicines, 6(12):48-62

The Indian Forester 140(1):86-92

Deepamol P.C. (2011)

Patel and Patel (2013)

Duggal et al. (2017)

Savithramma et al. (2014)

Venkatesh and Mahammad (2015)

Ph. D Thesis. Kannur University

International Journal of Scientific and Research Publications, 3(2):1-8

Asian Journal of Plant Science and Research, 7(2):37-44

Journal of Pharmaceutical Sciences and Research, 6(2):83-88

European Journal of Medicinal Plants, 9(4):1-29

Basha et al. (2015)

International Journal of Environment, 4(2):271-288

Parmar and Patel 2013

Mehta and Jain (2011)

International Journal of Plant Sciences, 6(2):362-366

Jaryan et al. (2010) 
40 Ethnobotanical studies of Sada Shiv sacred grove,district Kangra ,Himachal Pradesh

41 Sacred groves as ethnobotanical gene pools in tribal area of the western Himalaya, India

42 Enumeration of angiosperm medicinal plants of Gavisiddalingeshwara sacred grove,Chintanpalli of Yadgir District,Karnataka

43 Medicinal plants in the selected sacred groves of Kodungallur, Thrissur district, Kerala

44 Floristic composition and ethanobotanical practices of the sacred groves of Nemmara, Palakkad District, Kerala

45 Ethnobotanical documentation of a sacred Grove- Palakurumba temple, Olavanna in Kozhikode district, Kerala

46 An Ethnopharmacological survey on medicinal plants from sacred grove of Sree Puthiya Bhagavathi temple, Kalloori, Kannur (dist), Kerala

47 Ethno-Medico-Botanical studies on Katei Baba sacred grove and nearby area of Adhalwadi from Akole taluka, Ahmednagar district(Maharashtra)

48 Observation of medicinal importance of sacred plants of Chitrakoot region Satna (M.P.)

49 Inventory of ethnobotanicals and other systematic procedures for regional conservation of medicinal and sacred plants

50 An ethnomedicinal survey of medicinal plants from a sacred forest of western Odisha, India.

51 Ethno-Medicinal plants in five sacred groves in Cuddalore district, Tamilnadu, India

52 Medicinal plants conservation through sacred forest by ethnic tribals of Virudhunagar district,Tamil Nadu

53 Ethnomedicinal studies on important medicinal plants in two sacred groves at Pudukottai district Tamil Nadu

54 Medicinal plants and their uses :A study of twelve sacred groves in Cuddalore and Villupuram districts, Tamil Nadu, India

55 Medicinal plants of sacred groves in Kanyakumari district southern Western Ghats

56 Ethno botanical study of medicinal plants of $\mathrm{Sr}$ Pancha Narasimha Swamy and Sri Matsyagiri Narasimha Swamy

57 Socio-cultural and ethnobotanical value of a sacred forest,Thal ke Dhar,Central Himalaya

58 Medicinal plant diversity in newly reported sacred grove of Pithoragarh District, Uttarakhand

59 Sacred groves: traditional plant conservation through deities
Sharma et al.

(2014)

Thaplyal et al.

Modi and Mathad

(2016)

Deepa et al. (2016)

Divya and

Manonmani (2013)

Reshma and Indulekha (2016)

Poovathur and

Joseph (2016)

Waghchaure et al. (2011)

Bala and Singh (2015)

Wagh and Jain (2015)

Pradhan et al. (2016)

Anbarashan and Anbarashan

(2010)

Rajendran and

Agarwal (2007)

Vani et al. (2016)

Karthik et al. (2016)

Sukumaran \& Raj(2010)

Rao (2015)

Negi (2005)

Singh et al. (2011)

Bhakat and Sen (2016)
Life Sciences Leaflets, 53:8996

The Indian Forester, 138(1):70-78

Journal of Global Biosciences, 5(1):3539-3558

Journal of Medicinal Plants Studies, 4(3):149-155

International Journal of Pharmaceutical Sciences and Business Management,1(1):917

Journal of Medicinal Plants

Studies, 4(4):296-298

International Journal of Advanced Science and Research, 1(8):24-35

International Journal of Pharma and Bio Sciences, 2(3):393-398

International Journal of Science and Research, 4(8):1783-1787

Environment Systems and Decisions, 35:143-156

International Journal of Phytomedicine, 8(3):325-332

Ethnobotanical Leaflets, $14: 774-780$

Indian Journal of Traditional Knowledge, 6(2):328-333

Advances in Applied Science Research, 7(2):123-127

International Education and Research Journal, 2(5):95-102

Indian Journal of Traditional Knowledge, 9(2)294-299

Journal of Medicinal Plants Studies, 3(3):37-42

Indian Journal of Traditional Knowledge, 4(2):190-198

The Indian Forester, 137(8):1005-1008

Plants the natural wonder: Challenges and Avenues, (eds.) Sumita Bandopadhyay, 
60 Sacred groves of West Midnapore district in West Bengal

61 An invetory of medicinal plants of some sacred groves of Purulia district, West Bengal

62 Biodiversity and ethnobotany of sacred groves In Bakura district,West Bengal

63 Role of sacred grove in conservation of medicinal plants

64 Plants of ethnobotanical importance in the sacred groves of Jaintia Hills of Meghalaya

65 Deogudi' sacred grove -A tribal concept of conservation of plants in Bastar district ,Chattisgarh

Dipak Kumar Hens, Partha

Sarathi De, Damodar Group, Burdwan, West Bengal, India. Pp 212-223.

Bhakat and Sen (2011)

Bhakat and Pandit (2004)

Basu R. (2009)

Bhakat and Pandit (2003)

Upadhya et al. (2005)

Rai and Tripathi (2008)
Recent Advances in Plant

Science ,Diversity and Conservation(Proceeding of UGC National Seminar 2011), Pp 37-43

The Indian Forester, 130(1):37-44

The Indian Forester, 135(6): 765-777

The Indian Forester, 129(2):224-232

The Indian Forester, 131(6):812-828

The Indian Forester, 134(12):1686-1695

\section{Dataset preparation}

We selected angiosperm members for detail analysis due to their dominant presence in all the studies, and verified the binomial with 'World Flora Online (www.worldfloraonline.org). For disease categorization and standard nomenclature, we have followed the 10th revision of the International Statistical Classification of Diseases and Related Health Problems (ICD-10) (World Health Organization 2004).

\section{Statistical analysis}

Summary statistics, such as taxonomic diversity, species used for treating different diseases, and plant part use were determined for the whole dataset. Disease prevalence was determined based on number of species use against specific organ system as per ICD-10 classification. We used relative frequency of citation (RFC) for shortlisting fifty most frequently used species. They were further analyzed through standard ethnobotanical indices [use value (UV), consensus value for plant parts (CPP) and fidelity level (FL)] for their distribution, use details, part use, and reliability against specific ailments to capture the major trends in ethnomedicinal practices. All indices were calculated using MS-Excel software.

\section{Grove prioritization}

To search for candidate members for implementation in rural healthcare, we attempted to identify grove or grove clusters as hotspots. The selection was made based on the assemblage of greater than fifty percent $(50 \%)$ of the prioritized species. We recognized that frequently cited species may not represent the true status of medicinal practices and information about the rare plants and their use could be lost. However, for broad regional and national level priority setting, one has to go for widely known species with higher acceptance across communities excluding lesser-known species which are localized in their use. Moreover, frequently cited species also indicate public consciousness towards their remedial power, traditional use, and substantial economic support through cultivation and business (Karki \& Williams 1999). Complementing this notion further, we have generated cumulative species distribution as well as thematic maps on grove prioritization and fidelity value distribution.

\section{Results}

\section{Taxonomic spectrum of the medicinal plant resources}

A total of 1247 medicinal species included under 711 genera and 152 families was documented in our analysis (Appendix 1). Among these, herbs were dominant plant form (35\%), followed by trees $(31 \%)$, shrubs (18\%) and climbers (14\%). A small fraction of invasive, exotic and lower group plant members has found their way to the list. The species pool was not evenly distributed among the families; out of the 152 plant families, $50 \%$ of the total species were from 15 families whereas 39 families possessed $75 \%$ of total species (Fig 1). Among 1247 species, 897 (71\%) were solely recorded from any single biogeographic region while the rest were shared between at least two regions. The Himalayas held maximum number of unique species (64\%) followed by the north- 
eastern region (62\%) and the Deccan peninsula (58\%) (Fig 2). When contribution of various families to species pool was examined, Fabaceae had the highest share $(10.5 \%)$ followed by Compositae, Lamiaceae, and Rubiaceae (4.3\% each).

\section{Diseases and remedial measures}

We conducted the analysis in two phases, i.e., with the whole dataset and the data pertaining to fifty prioritized species. Analyses to determine fidelity value and use value were conducted for prioritized species only.

\section{Disease category}

We recorded eighteen (18) categories of ailments from the full dataset following the nomenclature of ICD10. However, seven categories were more prevalent than others for fifty prioritized species (60$100 \%$ ). The seven dominant categories were diseases related to digestive system (17\%), infections and parasitic attacks (17\%), skin and subcutaneous tissues (15\%) and others (Fig 3).

\section{Species diversity in disease}

Taking account of the whole species pool, more than hundred species were employed against each disease category. To the higher end of the spectra, infections and parasitic attacks were treated with the highest number of species (366), followed by general health purposes (358 species), external injury and attacks (324 species) and respiratory problem (240 species). However, in each disease category, species distribution was skewed towards only handful of families. In general, $50 \%$ of the total species were represented by $11 \%-17 \%$ of the total families. The family contribution rose up to $44 \%$ when $75 \%$ of the total species was considered (Appendix 2).

\section{Useful plant parts}

We recorded an employment of variety of plant parts treating different diseases. In the whole data set, leaves (94\%) were the most frequently used across all forms of plants followed by stems (55\%) and roots $(53 \%)$. The same trend was observed for fifty prioritized species, where CPP value showed leaf as a dominant ingredient (CPP 0.47) followed by root (CPP 0.39) and stem (CPP 0.29) (Fig 4). Plant part use also tended to vary with habit type, trees exhibited maximum number of part usage $(6 \pm 1.41)$ in comparison to climbers $(4 \pm 1.4)$, herbs $(4 \pm 1.3)$, and shrubs $(5 \pm 1.06)$ (Fig 5$)$ as observed in prioritized species.

\section{Fidelity values (FL)}

The index varied widely from $9 \%$ to $100 \%$ for the prioritized species. A total of fifteen species out of fifty demonstrated $>50 \%$ FL value against specific treatments (Table 2). For instance, Gymnema sylvestre had highest fidelity value $(F L=100)$ for treating diabetes irrespective of reporting area. Similar results were also obtained for Ocimum tenuifolium ( $F L=91$, cough and cold), Tridax procumbens ( $\mathrm{FL}=80$, cut and wounds), and Syzygium cumini ( $F L=78.5$, diabetes). In contrast, few other popular remedies scored less e.g. Cissus quadrangularis ( $\mathrm{FL}=53.3$, bone fracture), Mangifera indica ( $\mathrm{FL}=53.3$, diarrhoea), Achyranthes aspera ( $F L=52.1$, animal bite), etc.

\section{Use value (UV)}

The use value for the selected species ranged from 0.03 to 0.78 indicating their diversity of use and availability across the study area (Table 3). Geographic distribution of species was moderately correlated with use value, i.e., widely distributed species generally had higher use-value indicating diverse use across communities and cultures (Kendall's tau $=0.425$, $p$-value $=0.00003$ ). Maximum use value was reported from Gloriosa superba (0.78) with 51 different types of use covering all recorded disease categories, while minimum value was shown by Gymnema sylvestre (0.03) with specific uses only in diabetes and fracture.

\section{Spatial distribution pattern}

The 65 shortlisted studies recorded 840 sacred groves from eighteen states of India. However, they were heterogeneously distributed. Tamil Nadu, Uttarakhand, West Bengal, and Andhra Pradesh outnumbered others reporting an average of seven studies from each. Biogeographic zone-wise, the Deccan peninsular region is over-represented in our dataset since majority of the studies $(43 \%)$ have been reported from this area. Considering enlisted groves, the number of studies do not exactly correspond to the grove numbers, as many surveyed multiple groves in a single study. Taking account of remedial measures, higher fidelity value (FL value) assigned to a species against specific diseases corresponded to their wider reporting area (Fig 6 $a, b)$. We have also identified 12 groves or grove clusters as hotspots based on $\geq 50 \%$ availability of highly cited species (Fig 7). These hotspots with greater number of popular species are recommended as primary candidate for connecting grove system with local healthcare. 


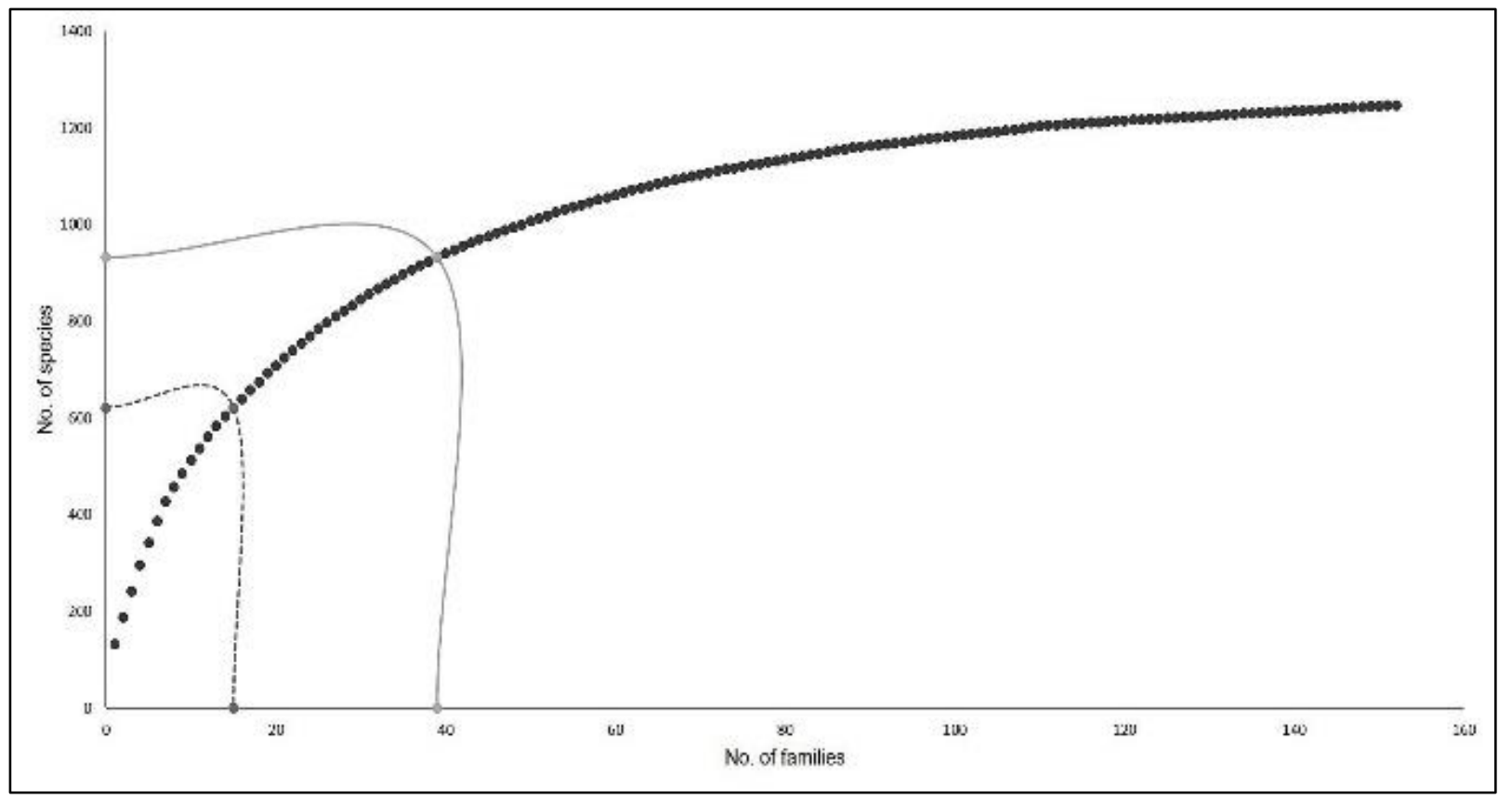

Figure 1. Cumulative graph of total species pool (1247 spp.) against 152 families. Dotted grey line represent 50\% species cut-off, and continuous grey line represents $75 \%$ species cut-off.

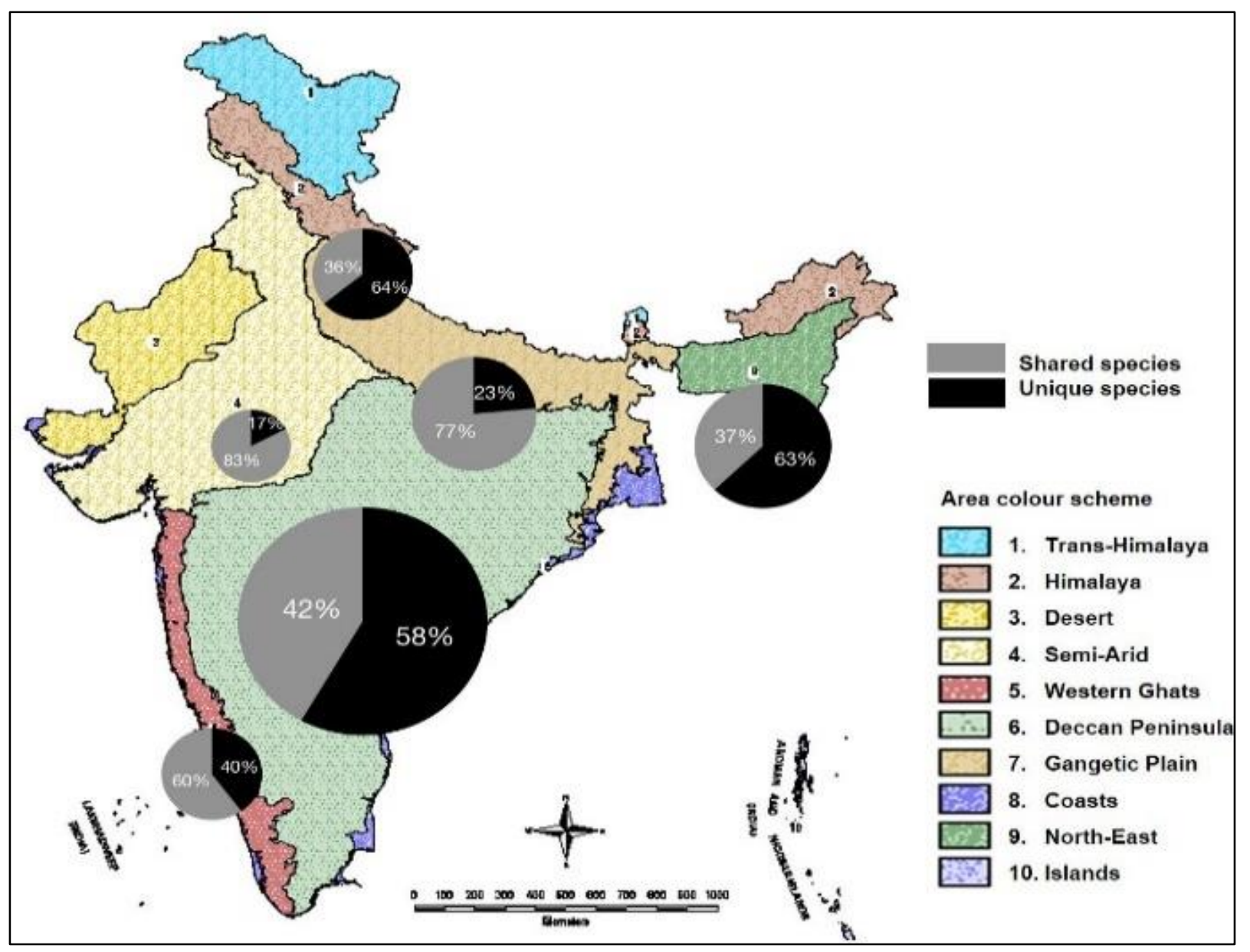

Figure. 2. Patterns of sacred grove species distribution in different biogeographic regions of India. Percentage of unique and shared species in different regions is presented in pie chart. (Map courtesy: Wildlife institute of India, 2000) 


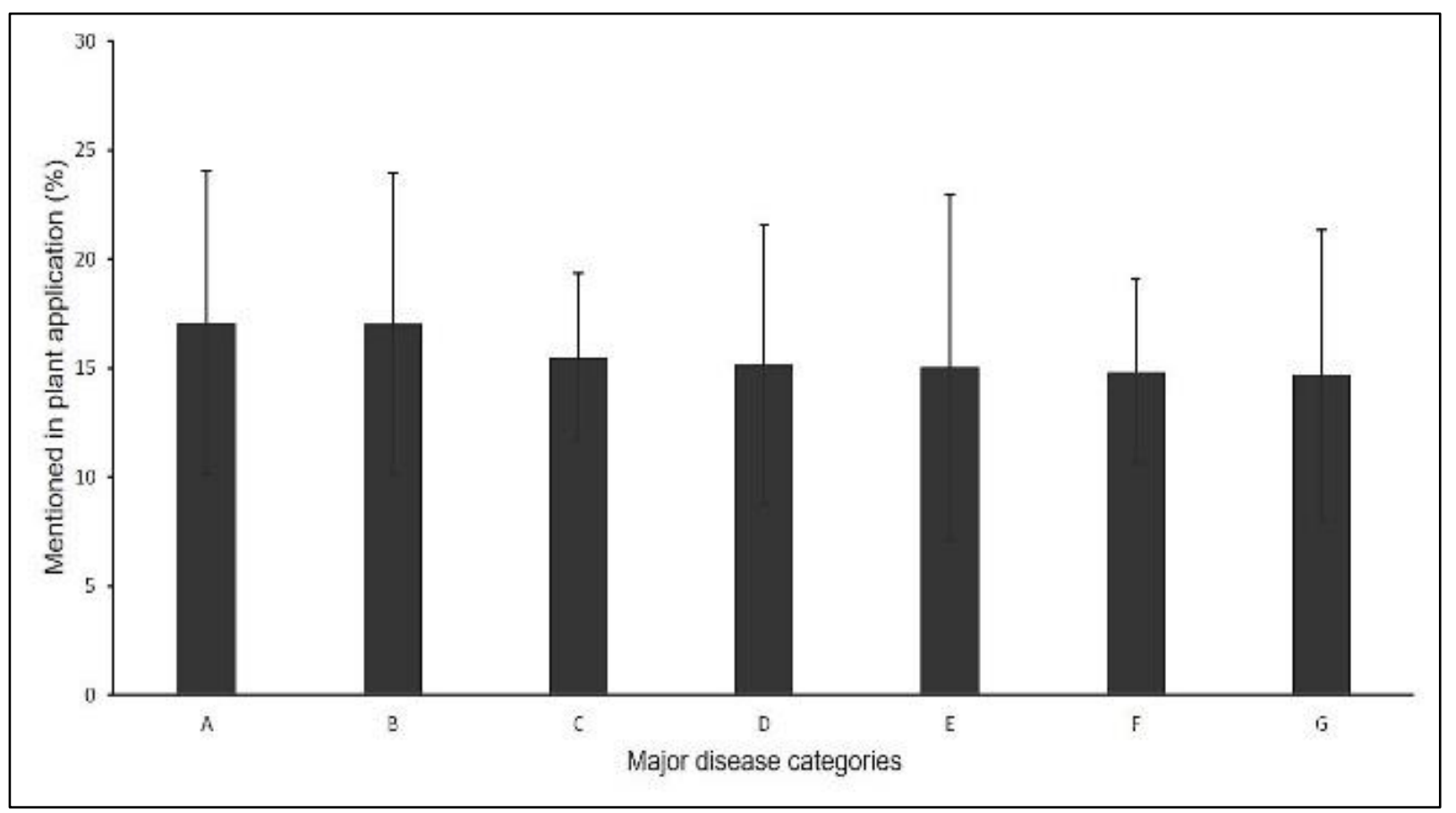

Figure 3. Prevalent disease categories from sacred grove based medicine practices. $A=$ digestive system; $B=$ infectious and parasitic diseases; $C=$ skin and sub-cutaneous tissues; $D=$ unspecified or general health problem; $\mathrm{E}=$ injury, poisoning and other external causes; $\mathrm{F}=$ respiratory system and $\mathrm{G}$ = genito-urinary system

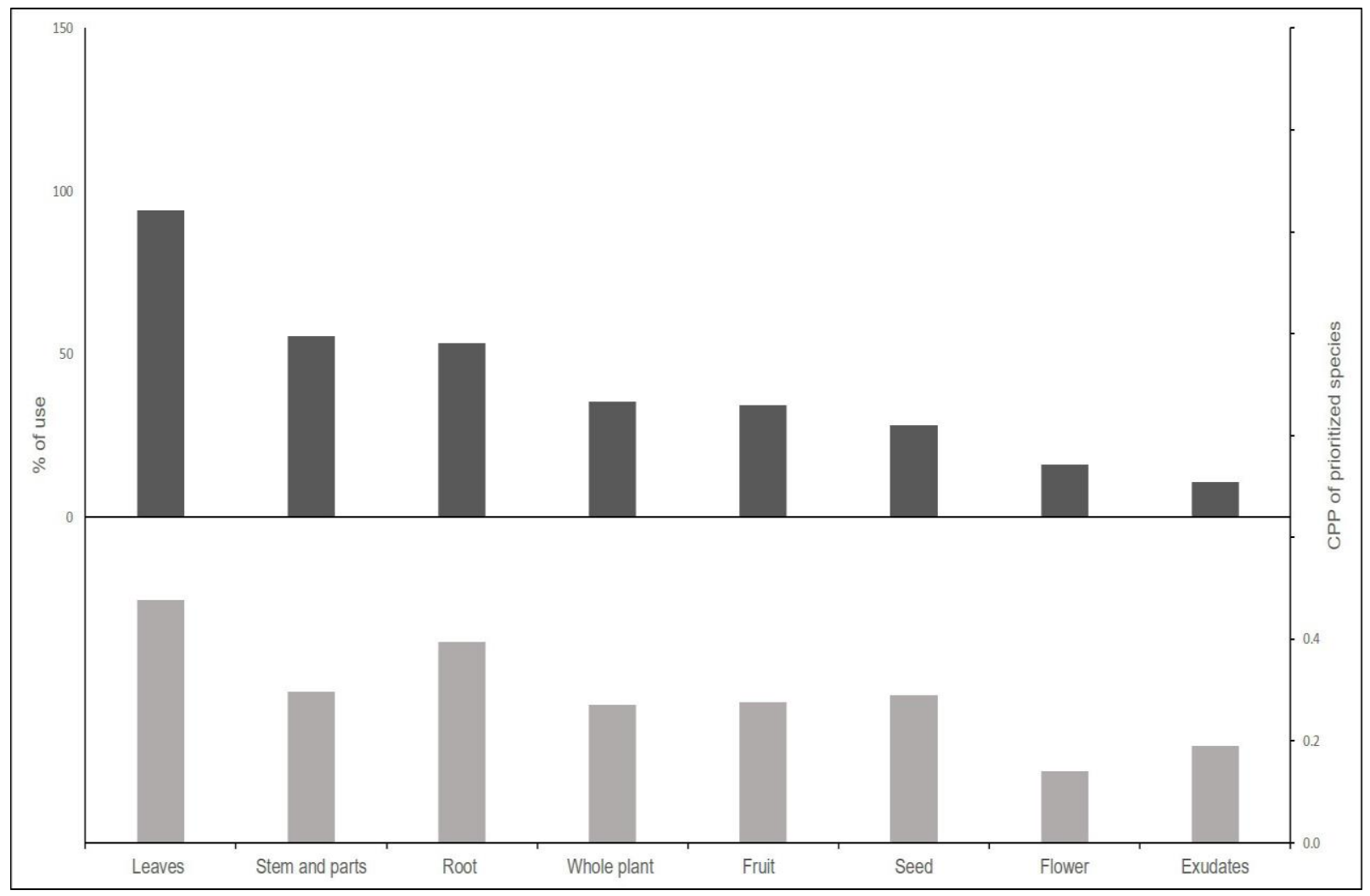

Fig 4. Preferred plant part use in medicine preparation. Upper panel shows findings from whole dataset (i.e. 1247 spp.) expressed in percentage (left axis); lower panel shows findings from fifty prioritised species expressed in CPP value (right axis). 


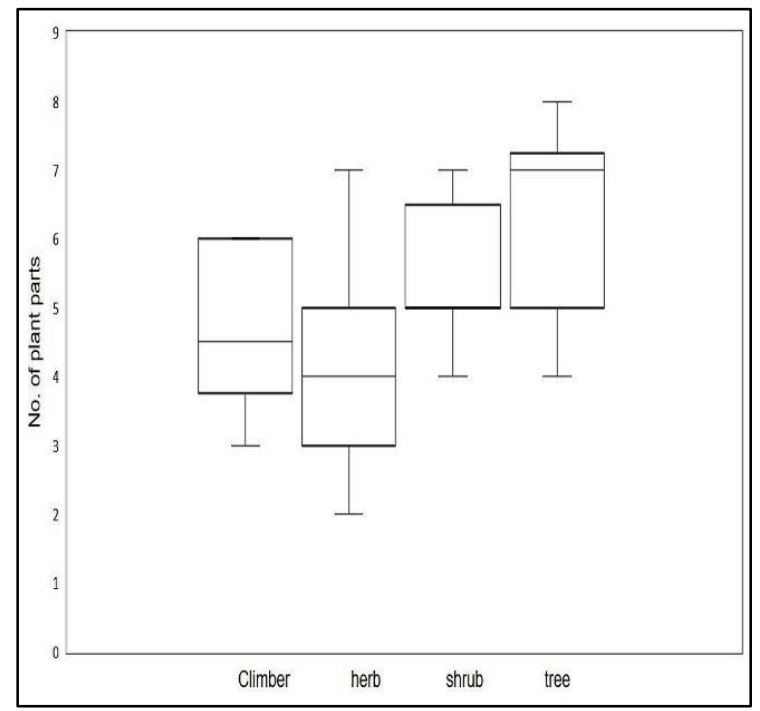

Figure 5. Pattern of plant part use for plant forms.

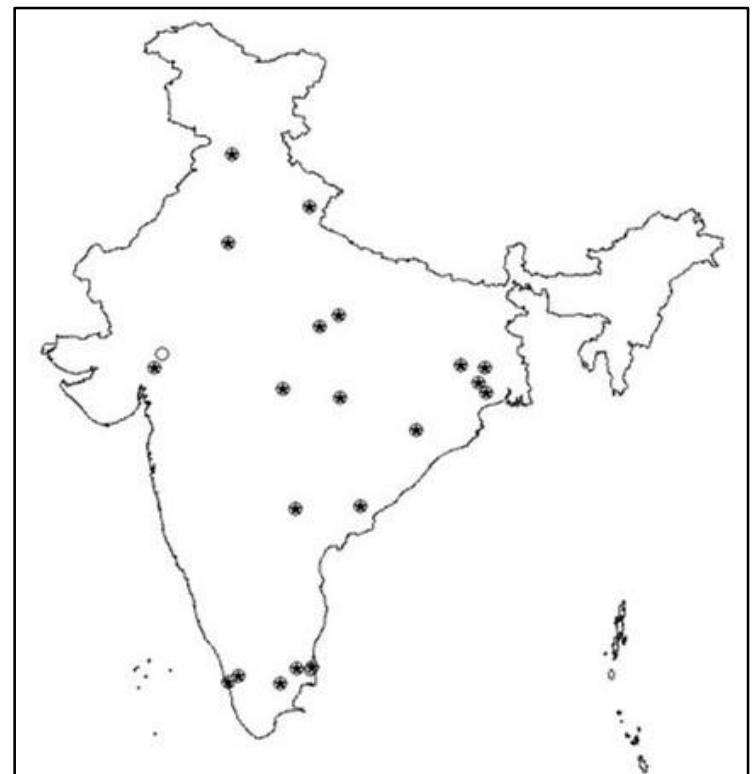

Figures $6 a$ \& b. Spatial Fidelity map for selected species; 6a) Ocimum tenuifolium (FD = 91 for cough and cold) and 6b) Azadirachta indica (FD $=69$ for skin disease). Dots indicate species geographic distribution (from consulted papers) and black dots indicate reporting of the specific use of the species against the disease for which the FL value was calculated.

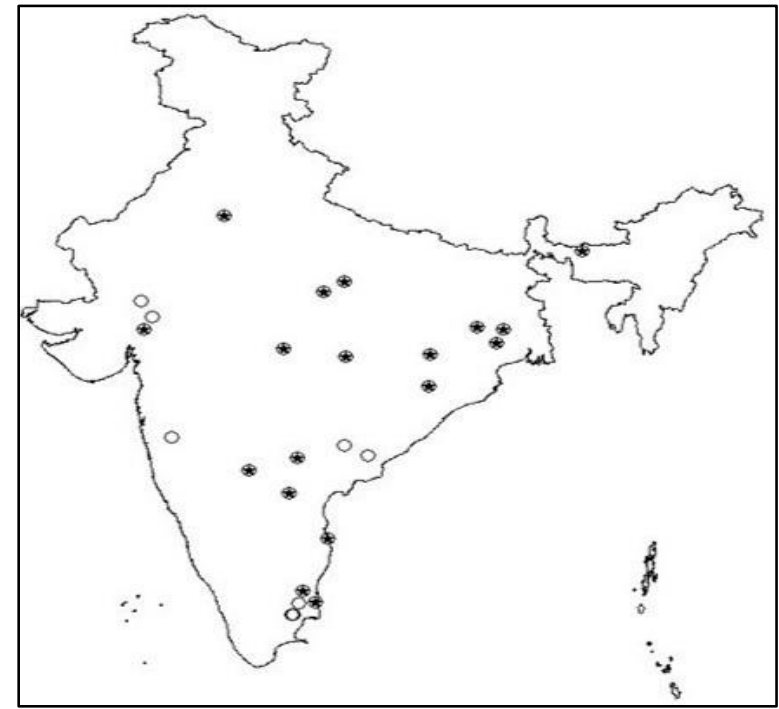

Figure 6b. Spatial Fidelity map for Azadirachta indica

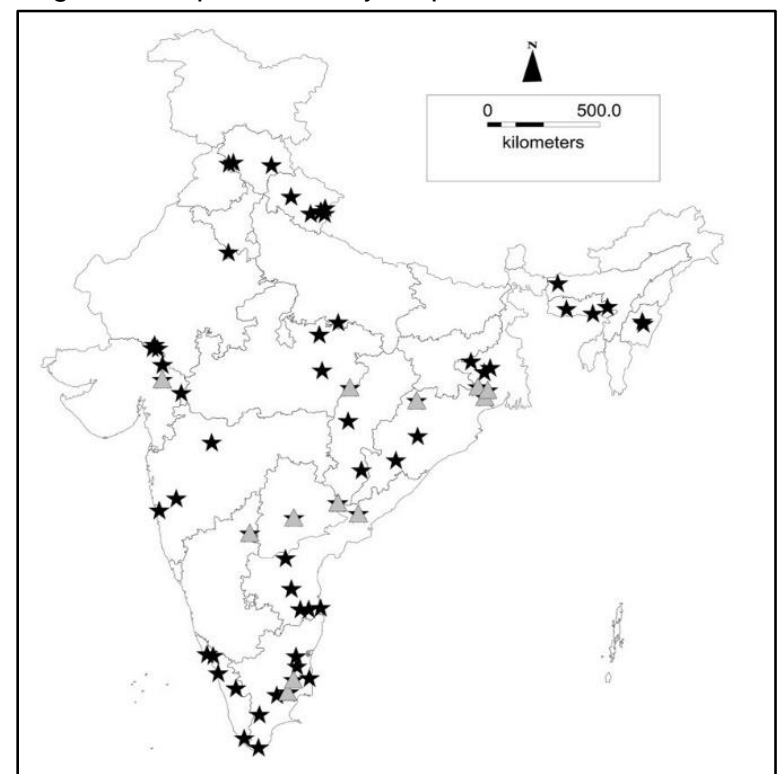

Figure 7. Distribution of studied grove / grove clusters across India. ${ }^{*}=$ case studies and $\mathbf{\Delta}=$ prioritised groves / grove clusters.

Table 2. Fidelity level of selected species against specific ailments (value $>50 \%$ )

\begin{tabular}{ccc}
\hline Species & Ailments treated & Fidelity value (\%) \\
\hline Gymnema sylvestre & Diabetes & 100 \\
Ocimum tenuiflorum & Cough and cold & 90.90909 \\
Tridax procumbens & Cut and wound & 80 \\
Syzygium cumini & Diabetes & 78.57143 \\
Argemone mexicana & Skin disease & 76.92308 \\
Acalypha indica & Skin disease & 75 \\
\hline
\end{tabular}




\begin{tabular}{ccc}
\hline Eclipta prostrata & Hair related problem & 71.42857 \\
Azadirachta indica & Skin disease & 69.23077 \\
Terminalia arjuna & Heart problems & 69.23077 \\
Boerhaavia diffusa & Liver problem & 66.66667 \\
Terminalia chebula & Digestive problem & 63.63636 \\
Aerva lanata & Kidney/Renal Stone & 54.54545 \\
Cissus quadrangularis & Bone fracture & 53.33333 \\
Mangifera indica & Diarrhoea & 53.33333 \\
Achyranthus aspera & Animal bite (scorpion, snake, dog) & 52.17391 \\
\hline
\end{tabular}

Table 3. Use value (UV) and Relative frequency of citation (RFC) for fifty prioritised species

\begin{tabular}{ccc}
\hline Species & Use value & Relative frequency of citation \\
\hline Abrus precatorius & 0.47692 & 0.35385 \\
Abutilon indicum & 0.35385 & 0.2 \\
Acalypha indica & 0.33846 & 0.21538 \\
Achyranthus aspera & 0.43077 & 0.36923 \\
Aegle marmelos & 0.63077 & 0.46154 \\
Aerva lanata & 0.2 & 0.18462 \\
Ageratum conyzoids & 0.33846 & 0.21538 \\
Alangium salviifolium & 0.35385 & 0.24615 \\
Albizia lebbeck & 0.46154 & 0.18462 \\
Andrographis paniculata & 0.4 & 0.33846 \\
Annona squamosa & 0.35385 & 0.21538 \\
Argimone mexicana & 0.29231 & 0.21538 \\
Asparagus racemosus & 0.49231 & 0.29231 \\
Azadirachta indica & 0.67692 & 0.46154 \\
Boerhaavia diffusa & 0.43077 & 0.24615 \\
Bombax ceiba & 0.30769 & 0.2 \\
Butea monosperma & 0.55385 & 0.26154 \\
Calotropis gigantea & 0.43077 & 0.21538 \\
Cassia fistula & 0.41538 & 0.38462 \\
Centella asiatica & 0.46154 & 0.23077 \\
Cheilocostus speciosus & 0.23077 & 0.16923 \\
Cissampelos pariera & 0.23077 & 0.18462 \\
Cissus quadrangularis & 0.26154 & 0.23077 \\
Curculigo orchioides & 0.43077 & 0.26154 \\
Cynodon dactylon & 0.49231 & 0.36923 \\
Datura metel & 0.23077 & 0.18462 \\
Eclipta prostata & 0.24615 & 0.16923 \\
Euphorbia hirta & 0.30769 & 0.30769 \\
Ficus benghalensis & 0.61538 & 0.36923 \\
Ficus religiosa & 0.69231 & 0.33846 \\
Gloriosa superba & 0.78462 & 0.27692 \\
Gymnema sylvestre & 0.03077 & 0.23077 \\
\hline
\end{tabular}




\begin{tabular}{ccc}
\hline Hemidesmus indicus & 0.49231 & 0.4 \\
Holarrhena pubescens & 0.24615 & 0.2 \\
Ichnocarpus frutescens & 0.2 & 0.2 \\
Lantana camara & 0.24615 & 0.2 \\
Mangifera indica & 0.27692 & 0.24615 \\
Mimosa pudica & 0.35385 & 0.21538 \\
Ocimum tenuiflorum & 0.61538 & 0.35385 \\
Oxalis corniculata & 0.33846 & 0.2 \\
Phyllanthus emblica & 0.24615 & 0.24615 \\
Plumbago zeylanica & 0.21538 & 0.2 \\
Syzygium cumini & 0.33846 & 0.24615 \\
Tamarindus indica & 0.41538 & 0.29231 \\
Terminalia arjuna & 0.44615 & 0.24615 \\
Terminalia bellirica & 0.38462 & 0.21538 \\
Terminalia chebula & 0.43077 & 0.18462 \\
Tinospora sinensis & 0.55385 & 0.33846 \\
Tridax procumbens & 0.30769 & 0.26154 \\
Vitex negundo & 0.44615 & 0.35385 \\
\hline
\end{tabular}

\section{Discussion}

\section{Taxonomic characteristics and assessment with other studies}

A total of 1247 medicinal species from 152 families illustrated the reliance of local people on a rich source of medicinal flora from the sacred groves. The high species diversity perhaps ensured their availability and sustainable usage for health benefits. Apart from angiosperms, moderate representation of lower group of plants (e.g., pteridophytes, lichens) highlighted the existing traditional knowledge-base on curative potential (Nayaka et al. 2010, Shirsat 2008). Similarly, use of invasive and exotic species in ethnomedicine (e.g., Lantana camara, Chromolena odorata, Sphagneticola sp.) demonstrated human adaptive strategy to utilize alternate resources (Sandilyan \& Klooster 2016), which implied the choice has been dynamic and contingent on local materials.

Considering ethnomedicinal plant resource, our study is fairly comparable with other findings, such as 8000 medicinal plants from 550 tribal communities revealed by All India Coordinated Research Project on Ethnobiology (AICRPE) (Pushpangadan et al. 2018); 782 species belonging to 132 families from the Eastern Ghats and the Deccan region (Karuppusamy \& Pullaiah 2017), and 528 species of 112 families from the Indo-Gangetic plains (Chowdhury et al. 2017). Despite our study being restricted to sacred groves, availability of such a large number of species clearly underscores the potential of the system as a reservoir of useful medicinal plants.

In terms of family level contribution, Fabaceae, Compositae, Lamiaceae, Rubiaceae, and Malvaceae have occupied the dominant position which corroborated other regional assessments of ethnomedicinal plants, e.g., the Eastern Ghats and the Indo-Gangetic plains (Chowdhury et al. 2017, Karuppusamy \& Pullaiah 2017). Pertinently, nearly same suite of families overwhelms the floral assemblage in overall angiosperm diversity in India (Arisdason \& Lakshminarasimhan 2017). It might be an indirect support for ecological apparency hypothesis, where apparent or abundant floral assemblages supposed to have greater contribution in livelihood maintenance (Albuquerque et al. 2015). Taxonomic inclination of this assembled ethnomedicinal pharmacopeia towards certain families can be statistically tested with the complete family monographs, but their unavailability at country-level impaired such an analysis. In spite of this limitation, a comparative assessment with the other works has depicted fairly similar trend across the tropical and sub-tropical regions. A total of 11 frequently used families from our list was shared by overly-used categories in the South African ethnomedicinal study (Douwes et al. 2008). Amiguet et al. (2006) highlighted the similarity in tropical useful medicinal floras among Chiapaz, Ecuador, and Veracruz, three southern neo-tropical regions, where Rubiaceae and Compositae have higher use along with few other families. Likewise, Leonti et al. (2003) 
have also reported the dominance of Fabaceae, Compositae, Euphorbiaceae, and Lamiaceae from Popoluca, Mexico.

\section{Distribution of medicinal plants}

The diversity of species was not homogeneous across administrative or biogeographic regions. The skewed distribution could be partly due to the access of the relevant studies from certain regions and lack of from the other. Although the biogeographic classification is very basic in contrast to the enormous local and regional variations, it provides a preliminary understanding on groves' association with certain ecosystems of India. In this regard, the Himalaya and the North-eastern regions demonstrated higher percentage of unique species (64\% and $62 \%$, respectively) owing to their distinct floral assemblage resulting from complex history (Mani 2012). On the other hand, higher percentage of unique species (58\%) from the Deccan peninsula could be attributed to its geographical expanse and better documentation, since 28 of 65 (43\%) studies are from this region. However, the assessment of uniqueness may have been overestimated due to the lack of sufficient data from the other regions. Alternatively, our grove-centric analyses may influence species comparison exercise as it selectively focused on grove flora ignoring the entire floral assemblage. Despite these limitations, these findings provided us with important clues related to floral availability, acceptance, and use pattern across cultures and communities. The aspect of shared species (i.e., remaining 29\%), the species documented from two or more regions, deserves further research to gain an insight into the processes leading to their multiple use and applications over a broader area. They may provide an opportunity to understand the larger context of human-environment interaction and socio-cultural knowledge sharing and transmission among communities - the factors are important to uncover basic ethnomedicinal principles.

\section{Rural healthcare system}

Our interpretation unraveled a distinct pattern in prevalent disease categories, spectrum of plant use, and its country-level variation in acceptance. The major advantages were a steady supply of authentic resource and a vast body of socially accepted traditional medical knowledge.

\section{Prevalent disease categories}

Eighteen disease categories and their remedial floral package indicated heavy reliance on the existing system as well as exploitation of resource diversity to fulfill the need. However, not all the categories were equally common, e.g., diseases related to digestive system, bacterial and parasitic attacks, skin problems, and external injuries were more treated than the others; the observation reflected the general trend of disease prevalence throughout the tropics (Cunningham et al. 2012, Mitra \& Mawson 2017). The causal factors could be multiple: malnutrition, ineffective food storage and family history; while, the agents inciting infections and skin problems are mostly external in nature (Negi \& Singh 2018). These are closely related to the surrounding environment and the way people lead their daily chores. Majority of the diseases in our study were water- or animalborne (e.g., cholera, diarrhoea, dysentery, malaria, scabies, rabies), and few were sexually transmitted (e.g., syphilis, gonorrhoea). Bacterial and parasitic agents were common in rural and forested landscapes, and their population shot up in specific seasons (e.g., rainy season). A general lack of awareness regarding their possible source and epidemiology was another reason of sickness (Anonymous 2017a). The other category, e.g., injuries and wounds could be caused by both biotic (e.g., snake, scorpion, insects, rodents and small mammals) and abiotic agents (accidental contacts). Summarizing, major diseases reported from the grove specific medicine system were related to low to moderately serious ailments associated with communities' life style choice and interaction with surroundings.

\section{Diversity in plant use spectrum}

It was found that nearly one-third of the total recorded plant species was in use to treat the dominant ailments. It was an indication that the treatment of a disease is not generally restricted to a few but employed a wide array of medicinal plants, an observation which also receives support from other studies (Jeeva et al. 2007, Sheikh et al. 2015). The finding of a number of species against a particular ailment also signified the flexibility, strong knowledge system, and rich resource base; it also insulated the loss of a species by replacement with other available and effective flora (Junior et al. 2015). On the other hand, employing a particular species against several diseases has been a common practice and the notion was supported by the fact that highly cited members demonstrated higher use values. The underlying reasons perhaps were easy availability, higher abundance, and cross-cultural knowledge base which allow experimentation against different ailments and facilitates cultural inclusion (Albuquerque et al. 2015, Leucena et al. 2012). However, species like Gymnema sylvestre and Gloriosa superba deviated from the predicted linear relation between citation index and use value. Both of them with moderate value of relative citation ( 0.23 and 0.27 , respectively) have shown extreme opposite magnitude of use value. G. sylvestre scored the lowest with its major use in diabetes, irrespective 
of its geographic and cultural presence. Its overly acceptance against diabetes could be an example of acquired knowledge through sharing of information or an independently perceived time-tested experience. Although the referred studies claimed to gather information from the local communities, the chances of information transfer from codified knowledge (i.e., Ayurvedic/Siddha/Unani) cannot be overruled (Biswas et al. 2017, Chandran 2016). On the other end of the spectrum, G. superba reportedly used in 51 ailments (highest among the priority species) portrayed its high acceptance among communities, but for its multipurpose use. The multifarious use of $G$. superba was in agreement with other studies where ethno-medicinal, pharmacological, and botanical aspects of the species have been discussed at length (Ashokkumar 2015, Padmapriya et al. 2015). Likewise, there were reviews on other plants, such as Azadirachta indica, Syzygium cumini, Ocimum tenuifolium (Ayyanar \& Suresh-Babu 2012, Biswas et al. 2002, Gupta et al. 2002) indicating their wider acceptance but multicommunity compilations, use-value determination, spatial patterns have rarely been described (but see Jain 2004, Srikanth et al. 2017).

\section{Reliability in plant use}

Evaluation of medicinal information from sacred groves revealed a considerable similarity in species and plant part use. Contrary to the popular use of the fidelity value index in one particular area, we have attempted to use the index to capture the acceptance level of a species throughout the country that may act as an indicator of its reliability. Inclusion of spatial dimension in reliability measure was an important addition to this study since it strengthened the widely held view on therapeutic potential of a plant. For instance, the common beliefs advocate the use of Gymnema sylvestre and Syzygium cumini in diabetes, Ocimum tenuifolium in cough and cold, which were quantitatively validated employing this index. The wider spatial distribution of the species with higher fidelity values also indicated broader cultural geographic acceptance than localized reliance. Jain (2004) earlier in his assessment of credibility of traditional medicinal knowledge performed a point-based credibility exercise to identify widely accepted plants against certain ailments. His findings demonstrated the crosscommunity applications of $G$. sylvestre and S. cumini in diabetes, Boerhaavia diffusa in liver problems which was in concord with our findings.

Among all, leaves appeared to be the most frequently used plant part. The underlying reason of such preference could be regular collections from herbs and trees where quantity and availability remained consistent throughout the year (Khan et al.
2014). Likewise, stem (or stem bark) and root were also regularly harvested probably due to the same reason. On the contrary, relatively lower use of reproductive parts (i.e., flower, fruits except seeds) may be explained by their seasonal availability, inconsistent quantity, and other uses in commercial, religious and cultural activities. Trees with highly differentiated morphology and longer life span allowed highest use of their parts than herbs and shrubs. Moreover, multiple other components (bark, secondary by-products, and aerial roots) were available from trees which collectively contributed to medicine preparation.

\section{Implementation of grove tradition to rural healthcare system}

The repertoire of medicinal flora conserved and managed in the sacred groves reinforced the fostering role of social institutions in biodiversity conservation and utilization (Colding \& Folke 2001, Persha et al. 2011). From our analysis, we found that sacred groves allowed treatment of a wide variety of ailments with the available medicinal plants. It earned a strong support from isolated and marginalized people for whom accessibility and affordability to standard healthcare is a distant goal. To bridge the gap between healthcare services and marginalized and rural communities, the Government of India took initiatives at different levels which included plurality in medical practices (Katoch et al. 2017). The major aim to incorporate plurality was to make the healthcare sector more inclusive so that people may exercise different choices according to their socio-economic status, cultural inclination, and comfort level (Samal 2015). Similarly, plurality is also beneficial from the administrative and technical standpoint since it offers an option for healthcare services without heavy reliance on infrastructure and administrative intervention. For example, plurality in Indian context revolves around the inclusion of AYUSH (Ayurveda, Naturopathy, Yoga, Unani, Siddha, and Homoeopathy) codified systems in national health mission so that people get the benefit of age-old traditional medicine system with all divergent choices (Katoch et al. 2017, Samal 2015). The co-location of AYUSH facilities with Primary Health Centre (PHC), Community Health Centre $(\mathrm{CHC})$, and District Hospital $(\mathrm{DH})$ is the judicious implementation of this very idea (Priya \& Sweta 2010). Medicinal plants are one of the integral component of the AYUSH system as the preparation mostly relies on resource availability, quality, and skilled handling. Pertinently, sacred groves in the villages could be an alternative resource for medicinal plants in the already established AYUSH program with an assurance for quality and availability. So, the need of the hour is the documentation of the medicinal plants and their 
proper maintenance. Our study, in this line, revealed several important aspects of ethnomedicinal practices, e.g., multiple species use in particular ailments, spatial validity in disease treatment (spatial fidelity assessment), and multiple usages of certain species; these underscore the long term association of traditional healers with local flora and environment. This valuable experience pool can be utilized in for the improvement of the AYUSH program to render higher cultural acceptance (Dehury \& Chatterjee 2016), since ethnomedicinal knowledge is informally accepted in medical research but lacks official recognition as a mode of treatment (Chandra \& Patwardhan 2018).

Employing data-driven prioritization exercise, we have identified 12 groves or grove clusters with greater than $50 \%$ of widely used species; these can be taken as a model candidate for mending the local connection between primary healthcare and ethnomedicinal expertise. The grove flora could be useful for medicine preparation under proper management and skilled manpower, whereas the local healer can be consulted for treatment modality and socio-cultural link establishment with local community. Moreover, our analyses also demonstrated higher value in spatial fidelity of many frequently cited species (e.g. Gymnema sylvestre, Syzygium cumini, Ocimum tenuiflorum, Eclipta prostrata), i.e., their use against specific disease is well established across the country; it ensures longterm acceptance across wider cultural geographic regions which is advantageous for AYUSH program. Our prioritization exercise is an initial attempt to identify those spots where frequently used species with multi-community reliance are available in a cluster; we, therefore, intentionally kept aside the region-specific rare species which may have equal importance in medicine practice, for the sake of broad country-wide pattern. For instance, the Himalaya possesses a large number of valuable medicinal plants in the sacred groves but majority of them are locality specific (e.g., Aconitum heterophyllum, Arnebia benthamii, Nardostachys grandiflora, etc) thus exhibit low score as national candidates. However, this exercise can be region specific, improved, and extended further by adding other parameters, e.g., details of treatments, medicine preparation method, and community involvement, which can be further assimilated into health policies for successful implementation.

\section{Conclusion}

The study summarized an enormous diversity of folk medicinal flora conserved, managed, and utilized in sacred groves throughout the country. It further exhibited a heavy dependence of the users for a wide variety of ailments common in tropical and subtropical rural landscapes; not limited to a few set, a diverse suite of plants has been generally applied to curing of different ailments.

Armed with data-driven inference, our study has stressed on the notion that sacred grove could be a strong base for traditional medicinal knowledge which can be complemented in local healthcare program as a part of national health mission agenda. Sacred groves, being a social institution, have an enduring association with local communities which hints at their embeddedness that raises their credibility in healthcare and promotes their conservation at local scale. A resurgence of popularity and awareness on ethnomedicine would resurrect the conservation and healthcare nexus liaising among the sacred grove stakeholders, local medical practitioners, and administrative bodies. In many areas, the community-led framework has already been in place which requires to be strengthened through proper planning, policy, and execution.

\section{Declarations}

\section{List of abbreviations:}

ICD10 $-10^{\text {th }}$ revision of the International Statistical Classification of Diseases and Related Health Problems

RFC - relative frequency of citation

UV - use value

CPP - consensus value for plant parts

FL - fidelity level

AICRPE - All India Coordinated Research Project on Ethnobiology

AYUSH - Ayurveda, Naturopathy, Yoga, Unani,

Siddha, and Homoeopathy

PHC - Primary Health Centre

$\mathrm{CHC}$ - Community Health Centre

$\mathrm{DH}$ - District Hospital

\section{Availability of data and materials:}

Available from the authors, on request

Consent for publication: Not applicable.

Conflict of interests: None declared.

Ethical approval and consent to participate: Not applicable.

Funding: None.

Authors' contributions: RR designed the study, collected, compiled, and analyzed the data. AR involved in data analysis. $R R$ and $A R$ jointly contributed in manuscript preparation.

\section{Acknowledgements}

Authors thank Sayantani Chanda and Sreevidya E.A. for their assistance in data collection.

\section{Literature cited}

Albert S, Porter J. 2015. Is 'mainstreaming AYUSH' the right policy for Meghalaya, northeast India? BMC Complementary and Alternative Medicine, 15:288 
Albert S, Nongrum M, Webb EL, Porter JDH, Kharkongor GC. 2015. Medical pluralism among indigenous peoples in northeast India - implications for health policy. Tropical Medicine and International Health, 20(7): 952-960

Albuquerque UP, Soldati GT, Ramos MA, de Melo JG, de Medeiros PM, Nascimento ALB, Júnior WSF. 2015. The influence of the environment on natural resource use: evidence of apparency. In Evolutionary ethnobiology. Springer, Cham, Pp 131147

Amiguet VT, Arnason JT, Maquin P, Cal V, Pablo SV, Luis PA. 2006. A regression analysis of Q'eqchi'Maya medicinal plants from southern Belize. Economic Botany, 60(1): 24-38. https://doi.org/10.1663/0013-0001

Anonymous 2017. National Health Policy. Ministry of Health and Family Welfare, Government of India. URL: https://mohfw.gov.in/documents/policy (last accessed 15th January 2020)

Anonymous. 2017a. Tribal health in India - Bridging the gap and a roadmap for the future-executive summary and recommendations. Ministry of Health and Family Welfare and Ministry of Tribal Affairs, Government of India.

Anyinam C, Kalipeni E, Zeleza PT. 1999. Ethnomedicine, sacred spaces, and ecosystem preservation \& conservation in Africa. In Sacred Spaces and Public Quarrels: African Cultural and Economic Landscapes. Edited by Zeleza PT, Kalipeni E., Africa World Press, Inc.

Arisdason W. Lakshminarasimhan P. 2016. Status of plant diversity in India: an overview. Central National Herbarium, Botanical Survey of India, Howrah.

Ashokkumar K. 2015. Gloriosa superba (L.): A Brief Review of its Phytochemical Properties and Pharmacology. International Journal of Pharmacognosy \& Phytochemical Research 7(6): 1190-1193

Ayyanar M, SureshBabu P. 2012. Syzygium cumini (L.) Skeels: A review of its phytochemical constituents and traditional uses. Asia Pacific Journal of Tropical Biomedicine 2: 3 240-246. doi: 10.1016/S2221-1691(12)60050-1

Bhattacharyya R, Asokan A, Bhattacharya P, Prasad R. 2009. The potential of certification for conservation and management of wild MAP resources. Biodiversity \& conservation 18(13): 3441-3451. doi: 10.1007/s10531-009-9653-z)

Biswas K, Chattopadhyay I, Banerjee RK, Bandyopadhyay U. 2002. Biological activities and medicinal properties of neem (Azadirachta indica). Current Science 82: 1336-1345

Biswas S, Shaw R, Bala S, Mazumdar A. 2017. Inventorization of some ayurvedic plants and their ethnomedicinal use in Kakrajhore forest area of West
Bengal. Journal of ethnopharmacology 197: 231241. DOI:10.1016/j.jep.2016.08.014

Blicharska M, Mikusiński G, Godbole A, Sarnaik J. 2013. Safeguarding biodiversity and ecosystem services of sacred groves - experiences from northern Western Ghats. International Journal of Biodiversity Science, Ecosystem Services \& Management, 9:4, 339-346, DOI: $10.1080 / 21513732.2013 .835350$

Chandra S, Patwardhan K. 2018. Allopathic, AYUSH and informal medical practitioners in rural India - a prescription for change. Journal of Ayurveda \& Integrative Medicine 9:143-150

Chandran MS. 2016. From the shadows of legitimacy problems and prospects of folk healing in India. Journal of Traditional \& Folk Practices 2,3,4 (1): 74-95

Chowdhury HR, Mandal SK, Pullaiah T. 2017. Ethnomedicinal plants of the Indo-Gangetic region and central India. In Ethnobotany of India, Volume 5, Apple Academic Press, Pp 127-199.

Colding J, Folke C. 2001. Social taboos: "invisible" systems of local resource management \& biological conservation. Ecological applications 11(2): 584600. DOI: $10.2307 / 3060911$

Cunningham AB, Shanley P, Laird S. 2012. Health, habitats \& medicinal plant use. In Human Health \& Forests, Routledge, Pp 57-84.

Currie E, Schofield J, Perez FO, Quiroga D. 2018. Health beliefs, healing practices \& medico-ritual frameworks in the Ecuadorean Andes: the continuity of an ancient tradition. World archeology 50(3): 461479.

https://doi.org/10.1080/00438243.2018.1474799

Dehury RK, Chatterjee SC. 2016. Dissociated reality vis-a-vis integrative planning of AYUSH in Maternal Health Program: A situational analysis in Jaleswar block of Balasore district of Odisha, India. Journal of Ayurveda \& Integrative Medicine 7:124-131

de Lucena RFP, de Medeiros PM, de Lima Araújo E, Alves AGC, de Albuquerque UP. 2012. The ecological apparency hypothesis \& the importance of useful plants in rural communities from Northeastern Brazil: An assessment based on use value. Journal of Environmental Management 96(1): 106-115. doi: 10.1016/j.jenvman.2011.09.001

Douwes E, Crouch NR, Edwards TJ, Mulholland DA. 2008. Regression analyses of southern African ethnomedicinal plants: informing the targeted selection of bioprospecting \& pharmacological screening subjects. Journal of Ethnopharmacology 119(3): 356-364. doi:10.1016/j.jep.2008.07.040

Gupta SK, Prakash J, Srivastava S. 2002. Validation of traditional claim of Tulsi, Ocimum sanctum Linn. as a medicinal plant. Indian Journal of Experimental Biology 40: 765-773 
Hollard G, Sene O. 2016. Social capital \& access to primary health care in developing countries: Evidence from Sub-Saharan Africa. Journal of Health Economics 45:1-11.

Holley J, Cherla K. 1998. Medicinal plants sector in India: a review. Medicinal and Aromatic Plants Program in Asia (MAPPA). IDRC/SARO New Delhi 110003, India

Hone T, Macinko J, Millett C. 2018. Revisiting AlmaAta: what is the role of primary health care in achieving the Sustainable Development Goals? The Lancet 392(10156):1461-1472.

Innocent E. 2016. Trends \& challenges toward integration of traditional medicine in formal healthcare system: Historical perspectives \& appraisal of education curricula in Sub-Sahara Africa. Journal of Intercultural Ethnopharmacology, 5:312-316

Jain SK. 2004. Credibility of traditional knowledgethe criterion of multilocational \& multiethnic use. Indian Journal of Traditional Knowledge 3(2): 137153

Jeeva GM, Jeeva S, Kingston C. 2007. Traditional treatment of skin diseases in South Travancore, southern peninsular India. Indian Journal of Traditional Knowledge 6(3): 498-501

Júnior WSF, Nascimento ALB, Ramos MA, de Medeiros PM, Soldati GT, Santoro FR, ReyesGarcía V, Albuquerque UP. 2015. Resilience \& adaptation in social-ecological systems. In Evolutionary ethnobiology, Springer, Cham, Pp 105119.

Karki M, Williams JT. 1999. Priority species of medicinal plants in South Asia. Medicinal and Aromatic Plants Program in Asia(MAPPA), International Development Research Centre, New Delhi, India.

Karuppusamy S, Pullaiah T. 2016. Ethnomedicinal Plants of Eastern Ghats and Adjacent Deccan Region. In Ethnobotany of India, Volume 1. Apple Academic Press, Pp 235-322.

Katoch D, Sharma JS, Banerjee S, Biswas R, Das B, Goswami D, Harwansh RK, Katiyar CK, Mukherjee PK. 2017. Government policies \& initiatives for development of Ayurveda. Journal of Ethnopharmacology 197: 25-31.

Khan I, AbdElsalam NM, Fouad H, Tariq A, Ullah R, Adnan M. 2014. Application of ethnobotanical indices on the use of traditional medicines against common diseases. Evidence-Based Complementary \& Alternative Medicine 2014: 21. http://dx.doi.org/10.1155/2014/635371

Khumbongmayum AD, Khan ML, Tripathi RS. 2005. Ethnomedicinal plants in the sacred groves of Manipur. Indian Journal of Traditional Knowledge 4(1): 21-32
Leonti M, Fernando RR, Sticher O, Heinrich M. 2003. Medicinal flora of the Popoluca, Mexico: a botanical systematical perspective. Economic Botany (2003) 57: 218-230. https://doi.org/10.1663/0013-0001

Mani MS. 2012. Ecology and biogeography in India (Vol. 23). Springer Science \& Business Media.

Minocha AA. Medical pluralism \& health services in India. 1980. Social Science \& Medicine. Part B: Medical Anthropology. 14(4):217-223.

Mishra A, Nambiar D, Madhavan H. 2018. The Making of 'Local Health Traditions' in India. Economic \& Political Weekly 53(30): 41-49.

Mitra A, Mawson A. 2017. Neglected tropical diseases: epidemiology \& global burden. Tropical medicine \& infectious disease, 2(3), p.36. doi: 10.3390/tropicalmed2030036

Nayaka S, Upreti DK, Khare R. 2010. Medicinal lichens of India. In Drugs from Plants Edited by P.C. Trivedi. Avishkar Publishers, Distributors, Jaipur, India, Pp 1-54.

Negi DP, Singh MM. 2018. Tribal Health and Healthcare Beliefs in India: A Systematic Review. International Journal of Research in Social Sciences 8(5) 219

Ogundele SO. 2007. Aspects of indigenous medicine in south-western Nigeria. Studies on Ethnomedicine 1(2): 127-133. https://doi.org/10.1080/09735070.2007.11886305

Padmapriya S, Rajamani K, Sathiyamurthy VA. 2015. Glory lily (Gloriosa superba L.)-A review. International Journal of Current Pharmaceutical Review \& Research 7(1): 43-49.

Pandve HT, Pandve TK. 2013. Primary healthcare system in India: Evolution and challenges. International Journal of Health System \& Disaster Management 1(3): 125-128.

Pedersen D, Baruffati V. 1985. Health and traditional medicine culture in Latin America and the Caribbean. Social Science and Medicine 21(1): 5-12. https://doi.org/10.1016/0277-9536(85)90282-5

Persha L, Agrawal A, Chhatre A. 2011. Social and ecological synergy: local rulemaking, forest livelihoods, and biodiversity conservation. Science 331(6024): 1606-1608. DOI: 10.1126/science. 1199343

Priya R, Shweta AS. 2010. Status and role of AYUSH and local health traditions under the national rural health mission. National Health Systems Resource Centre, National Rural Health Mission, Ministry of Health \& Family Welfare, Government of India, New Delhi

Pushpangadan P, George V, ljinu TP, Chithra MA. 2018. All India coordinated research project on ethnobiology and genesis of ethnopharmacology research in India including benefit sharing. Annals of 
Phytomedicine 7(1): 5-12. DOI: 10.21276/ap.2018.7.1.2

Rai PK, Lalramnghinglova $H .2011$. Ethnomedicinal plants of India with special reference to an IndoBurma hotspot region: An overview. Ethnobotany research \& applications 9: 379-420.

Ray R, MDS Chandran, Ramachandra TV. 2014. Biodiversity and ecological assessments of Indian sacred groves. Journal of Forestry Research 25(1): 21-28. doi: 10.1007/s11676-014-0429-2

Rudra S, Kalra A, Kumar A, Joe W. 2017. Utilization of alternative systems of medicine as health care services in India: Evidence on AYUSH care from NSS 2014. PLoS One 12:e0176916

Samal J. 2015. Situational analysis and future directions of AYUSH: An assessment through 5-year plans of India. Journal of Intercultural Ethnopharmacology 4:348-354. DOI: 10.5455/jice.20151101093011

Sandilyan S, van't Klooster CIEA. 2016. The other sides of invasive alien plants of India-With special reference to medicinal values. Journal for Nature Conservation 31: 16-21. https://doi.org/10.1016/j.jnc.2016.02.005

Sheehan HE. 2009. Medical pluralism in India: patient choice or no other options? Indian Journal of Medical Ethics 6(3): 138-141

Sheikh Y, Maibam BC, Biswas D, Laisharm S, Deb L, Talukdar NC, Borah JC. 2015. Anti-diabetic potential of selected ethno-medicinal plants of north east India. Journal of Ethnopharmacology 171: 3741. doi: 10.1016/j.jep.2015.05.030

Shirsat RP. 2008. Ethnomedicinal Uses of some common Bryophytes and Pteridophytes used by tribals of Melghat Region (MS), India. Ethnobotanical Leaflets 12: 690-92

Srikanth N, Singh S, Sharma BS, Khanduri S, Singh R, Maheswar T. 2017. Tribal Healthcare Research Program: An Overview of Central Council for Research in Ayurvedic Sciences Contributions. Journal of Drug Research Ayurvedic Science 2(2):118-148.

Unnikrishnan P. 2010. Role of Traditional Medicine in Primary Healthcare: An Overview of Perspectives and Challenges. Yokohama Journal of Social Sciences 14(6): 57-77

Venkatesh R, Mahammad KS. 2015. Ethnomedicinal plants in sacred groves in East Godavari district, Andhra Pradesh, India. European Journal of Medicinal Plants, 9(4): 1-29,

Verschuuren B. 2010. Sacred natural sites: Conserving nature \& culture. Routledge.

Voeks RA. 1996. Tropical forest healers and habitat preference. Economic Botany 50(4): 381-400. doi: 10.1007/BF02866520
World Flora Online consortium. http://www.worldfloraonline.org/organisation/WFO

World Flora Online Data. 2018.

World Health Organization, 2004. ICD-10: international statistical classification of deseases \& related health problems. In ICD-10: International statistical classification of deseases \& related health problems: tenth revision, 2nd ed. World Health Organization.

https://apps.who.int/iris/h\&le/10665/42980

Young A. 1983. The relevance of traditional medical cultures to modern primary healthcare. Social science and medicine 17(16): 1205-1211

Zank S. Hanazaki N. 2017. The coexistence of traditional medicine and biomedicine: A study with local health experts in two Brazilian regions. PLoS ONE 12(4): e0174731. https://doi.org/10.1371/journal.pone.0174731 


\section{Ethnobotany Research and Applications}

Appendix 1. Medicinal plants reported from the studied groves

\begin{tabular}{ll}
\hline Species & Family \\
\hline Acanthus ilicifolius Lour. & Acanthaceae \\
Acanthus leucostachyus Wall. ex Nees & Acanthaceae \\
Andrographis paniculata (Burm.f.) Nees & Acanthaceae \\
Andrographis alata (Vahl) Nees & Acanthaceae \\
Andrographis echioides (L.) Nees & Acanthaceae \\
Asystasia chelonoides Nees & Acanthaceae \\
Avicennia officinalis L. & Acanthaceae \\
Barleria buxifolia L. & Acanthaceae \\
Barleria cristata L. & Acanthaceae \\
Barleria cuspidata F.Heyne ex Nees & Acanthaceae \\
Barleria lupulina Lindl. & Acanthaceae \\
Barleria prionitis L. & Acanthaceae \\
Blepharis maderaspatensis (L.) B.Heyne ex Roth & Acanthaceae \\
Crossandra infundibuliformis (L.) Nees & Acanthaceae \\
Dicliptera bupleuroides Nees & Acanthaceae \\
Dicliptera chinensis (L.) Juss. & Acanthaceae \\
Dicliptera paniculata (Forssk.) I.Darbysh. & Acanthaceae \\
Ecbolium ligustrinum (Vahl) Vollesen & Acanthaceae \\
Ecbolium viride (Forssk.) Alston & Acanthaceae \\
Elytraria acaulis (L.f.) Lindau & Acanthaceae \\
Eranthemum purpurascens Wight ex Nees & \\
\hline & Acanthemum roseum (Vahl) R.Br. \\
\hline
\end{tabular}

\begin{tabular}{|c|c|}
\hline Hemigraphis hirta (Vahl) T.Anderson & Acanthaceae \\
\hline Hygrophila auriculata (Schumach.) Heine & Acanthaceae \\
\hline Justicia adhatoda L. & Acanthaceae \\
\hline Justicia betonica L. & Acanthaceae \\
\hline Justicia gendarussa Burm.f. & Acanthaceae \\
\hline Justicia glauca Rottler & Acanthaceae \\
\hline Justicia japonica Thunb. & Acanthaceae \\
\hline Lepidagathis cristata Willd. & Acanthaceae \\
\hline Peristrophe bicalyculata (Retz.) Nees & Acanthaceae \\
\hline Phlogacanthus thyrsiflorus Nees & Acanthaceae \\
\hline $\begin{array}{l}\text { Phlogacanthus thyrsiformis (Roxb. ex Hardw.) } \\
\text { Mabb. }\end{array}$ & Acanthaceae \\
\hline Ruellia prostrata Poir. & Acanthaceae \\
\hline Rungia pectinata (L.) Nees & Acanthaceae \\
\hline Strobilanthes ciliata Nees & Acanthaceae \\
\hline Strobilanthes scaber T.Anderson & Acanthaceae \\
\hline Thunbergia fragrans Roxb. & Acanthaceae \\
\hline Thunbergia grandiflora (Roxb. ex Rottl.) Roxb. & Acanthaceae \\
\hline Thunbergia laevis Nees & Acanthaceae \\
\hline Hydnocarpus macrocarpa Warb. & Achariaceae \\
\hline Hydnocarpus pentandrus (Buch.-Ham.) Oken & Achariaceae \\
\hline Hydnocarpus wightianus Blume & Achariaceae \\
\hline Acorus calamus $\mathrm{L}$. & Acoraceae \\
\hline Viburnum cotinifolium D. Don & Adoxaceae \\
\hline
\end{tabular}




\section{Ethnobotany Research and Applications}

\begin{tabular}{|c|c|}
\hline Viburnum foetidum Wall. & Adoxaceae \\
\hline Trianthema portulacastrum L. & Aizoaceae \\
\hline Achyranthes aspera L. & Amaranthaceae \\
\hline Aerva javanica (Burm.f.) Juss. ex Schult. & Amaranthaceae \\
\hline Aerva lanata (L.) Juss. & Amaranthaceae \\
\hline Allmania nodiflora (L.) R.Br. ex Wight & Amaranthaceae \\
\hline Alternanthera brasiliana (L.) Kuntze & Amaranthaceae \\
\hline Alternanthera pungens Kunth & Amaranthaceae \\
\hline Alternanthera sessilis (L.) R.Br. ex DC. & Amaranthaceae \\
\hline Amaranthus caudatus $\mathrm{L}$. & Amaranthaceae \\
\hline Amaranthus spinosus L. & Amaranthaceae \\
\hline Amaranthus tricolor $\mathrm{L}$. & Amaranthaceae \\
\hline Amaranthus blitum L. & Amaranthaceae \\
\hline Celosia argentea L. & Amaranthaceae \\
\hline Chenopodium album L. & Amaranthaceae \\
\hline Cyathula prostrata (L.) Blume & Amaranthaceae \\
\hline Cyathula tomentosa (Roth) Moq. & Amaranthaceae \\
\hline $\begin{array}{l}\text { Dysphania ambrosioides (L.) Mosyakin \& } \\
\text { Clemants }\end{array}$ & Amaranthaceae \\
\hline Gomphrena serrata L. & Amaranthaceae \\
\hline Pupalia lappacea (L.) Juss. & Amaranthaceae \\
\hline Allium cepa L. & Amaryllidaceae \\
\hline Allium sativum L. & Amaryllidaceae \\
\hline Crinum asiaticum $\mathrm{L}$. & Amaryllidaceae \\
\hline
\end{tabular}

\begin{tabular}{|c|c|}
\hline Anacardium occidentale $\mathrm{L}$. & Anacardiaceae \\
\hline Buchanania axillaris (Desr.) Ramamoorthy & Anacardiaceae \\
\hline $\begin{array}{l}\text { Buchanania cochinchinensis (Lour.) } \\
\text { M.R.Almeida }\end{array}$ & Anacardiaceae \\
\hline Holigarna arnottiana Hook.f. & Anacardiaceae \\
\hline Holigarna caustica (Dennst.) Oken & Anacardiaceae \\
\hline Lannea coromandelica (Houtt.) Merr. & Anacardiaceae \\
\hline Mangifera indica L. & Anacardiaceae \\
\hline Rhus chinensis Mill. & Anacardiaceae \\
\hline Rhus mysorensis G.Don & Anacardiaceae \\
\hline Rhus parviflora Roxb. & Anacardiaceae \\
\hline Rhus succedanea L. & Anacardiaceae \\
\hline Semecarpus anacardium L.f. & Anacardiaceae \\
\hline Spondias pinnata (L. f.) Kurz & Anacardiaceae \\
\hline Ancistrocladus heyneanus Wall. ex J.Graham & Ancistrocladaceae \\
\hline Annona reticulata $\mathrm{L}$. & Annonaceae \\
\hline Annona squamosa $\mathrm{L}$. & Annonaceae \\
\hline Artabotrys hexapetalus (L.f.) Bhandari & Annonaceae \\
\hline Miliusa tomentosa (Roxb.) J.Sinclair & Annonaceae \\
\hline Polyalthia longifolia (Sonn.) Thwaites & Annonaceae \\
\hline Uvaria narum A.DC. & Annonaceae \\
\hline Angelica glauca Edgew. & Apiaceae \\
\hline Bunium persicum (Boiss.) B.Fedtsch. & Apiaceae \\
\hline Centella asiatica (L.) Urb. & Apiaceae \\
\hline
\end{tabular}




\section{Ethnobotany Research and Applications}

\begin{tabular}{|c|c|}
\hline Chaerophyllum reflexum Aitch. & Apiaceae \\
\hline Ferula jaeskeana C.B.Clarke & Apiaceae \\
\hline Heracleum lanatum Michx. & Apiaceae \\
\hline Narthex asafoetida Falc. ex Lindl. & Apiaceae \\
\hline Oenanthe javanica (Blume) DC. & Apiaceae \\
\hline Peucedanum nagpurense Prain & Apiaceae \\
\hline Pimpinella diversifolia DC. & Apiaceae \\
\hline Allamanda cathartica L. & Apocynaceae \\
\hline Alstonia scholaris (L.) R. Br. & Apocynaceae \\
\hline Alstonia venenata $\mathrm{R} . \mathrm{Br}$. & Apocynaceae \\
\hline Calotropis gigantea (L.) Dryand. & Apocynaceae \\
\hline Calotropis procera (Aiton) Dryand. & Apocynaceae \\
\hline Caralluma adscendens (Roxb.) R.Br. & Apocynaceae \\
\hline Caralluma stalagmifera C.E.C.Fisch. & Apocynaceae \\
\hline Carissa carandas L. & Apocynaceae \\
\hline Carissa spinarum L. & Apocynaceae \\
\hline Cascabela thevetia (L.) Lippold & Apocynaceae \\
\hline Catharanthus pusillus (Murray) G.Don & Apocynaceae \\
\hline Catharanthus roseus (L.) G.Don & Apocynaceae \\
\hline Ceropegia attenuata Hook. & Apocynaceae \\
\hline Ceropegia bulbosa Roxb. & Apocynaceae \\
\hline Ceropegia candelabrum L. & Apocynaceae \\
\hline Ceropegia vincifolia Hook. & Apocynaceae \\
\hline Chonemorpha fragrans (Moon) Alston & Apocynaceae \\
\hline
\end{tabular}

Cryptolepis dubia (Burm.f.) M.R.Almeida

Cryptostegia grandiflora Roxb. ex R.Br.

Cynanchum viminale (L.) L.

Dregea volubilis (L.f.) Benth. ex Hook.f.

Gymnema decaisneanum Wight

Gymnema sylvestre (Retz.) R.Br. ex Sm.

Hemidesmus indicus (L.) R. Br. ex Schult.

Holarrhena pubescens Wall. ex G.Don

Hoya parviflora Wight

Ichnocarpus frutescens (L.) W.T.Aiton

Leptadenia reticulata (Retz.) Wight \& Arn.

Nerium oleander $\mathrm{L}$.

Pergularia daemia (Forssk.) Chiov.

Plumeria obtusa L.

Plumeria rubra L.

Rauvolfia serpentina (L.) Benth. ex Kurz

Rauvolfia tetraphylla L.

Sarcostemma acidum (Roxb.) Voigt

Secamone emetica (Retz.) R. Br. ex Schult.

Tabernaemontana alternifolia L.

Tabernaemontana divaricata (L.) R.Br. ex Roem \& Schult.

Telosma pallida (Roxb.) W. G. Craib

Thevetia neriifolia Juss. ex Steud.
Apocynaceae

Apocynaceae

Apocynaceae

Apocynaceae

Apocynaceae

Apocynaceae

Apocynaceae

Apocynaceae

Apocynaceae

Apocynaceae

Apocynaceae

Apocynaceae

Apocynaceae

Apocynaceae

Apocynaceae

Apocynaceae

Apocynaceae

Apocynaceae

Apocynaceae

Apocynaceae

Apocynaceae

Apocynaceae

Apocynaceae 


\section{Ethnobotany Research and Applications}

\begin{tabular}{ll}
\hline Tylophora asthmatica (L. f.) Wight \& Arn. & Apocynaceae \\
Tylophora indica (Burm. f.) Merr. & Apocynaceae \\
Tylophora rotundifolia Buch.-Ham. ex Wight & Apocynaceae \\
Vallaris solanacea (Roth) Kuntze & Apocynaceae \\
Wrightia tinctoria R.Br. & Apocynaceae \\
Ilex embelioides Hook.f. & Aquifoliaceae \\
lex khasiana Purkay. & Aquifoliaceae \\
Alocasia macrorrhizos (L.) G.Don & Araceae \\
Amorphophallus paeoniifolius (Dennst.) Nicolson & Araceae \\
Amorphophallus sylvaticus (Roxb.) Kunth & Araceae \\
Arisaema consanguineum Schott & Araceae \\
Arisaema jacquemontii Blume & Araceae \\
Arisaema tortuosum (Wall.) Schott & Araceae \\
Colocasia esculenta (L.) Schott & Araceae \\
Lasia spinosa (L.) Thwaites & Araceae \\
Pothos curtisii Hook.f. & Araceae \\
Pothos scandens L. & Araceae \\
Remusatia vivipara (Roxb.) Schott & Araceae \\
Rhaphidophora hookeri Schott & Araceae \\
Sauromatum venosum (Dryand. ex Aiton) Kunth & Araceae \\
Scindapsus officinalis (Roxb.) Schott & Araceae \\
Hedera nepalensis K.Koch & Araliaceae \\
Hydrocotyle javanica Thunb. & Araliaceae \\
Macropanax undulatus (Wall. ex G.Don) Seem. & Araliaceae \\
\hline & \\
\hline
\end{tabular}

Schefflera hypoleuca (Kurz) Harms

Trevesia palmata (Roxb. ex Lindl.) Vis.

Areca catechu L.

Borassus flabellifer L.

Caryota urens L.

Cocos nucifera $\mathrm{L}$.

Phoenix acaulis Roxb.

Phoenix dactylifera L.

Phoenix loureiroi Kunth

Phoenix pusilla Gaertn.

Phoenix sylvestris (L.) Roxb.

Aristolochia bracteolata Lam.

Aristolochia indica L.

Aristolochia littoralis Parodi

Aristolochia saccata Wall.

Agave americana L.

Agave sisalana Perrine

Asparagus adscendens Roxb.

Asparagus filicinus Buch.-Ham. ex D.Don

Asparagus racemosus Willd.

Chlorophytum borivilianum Santapau \& R.R.Fern.

Chlorophytum breviscapum Dalzell

Chlorophytum tuberosum (Roxb.) Baker
Araliaceae

Araliaceae

Arecaceae

Arecaceae

Arecaceae

Arecaceae

Arecaceae

Arecaceae

Arecaceae

Arecaceae

Arecaceae

Aristolochiaceae

Aristolochiaceae

Aristolochiaceae

Aristolochiaceae

Asparagaceae

Asparagaceae

Asparagaceae

Asparagaceae

Asparagaceae

Asparagaceae

Asparagaceae

Asparagaceae 


\section{Ethnobotany Research and Applications}

\begin{tabular}{|c|c|}
\hline Drimia indica (Roxb.) Jessop & Asparagaceae \\
\hline Furcraea foetida (L.) Haw. & Asparagaceae \\
\hline Ledebouria revoluta (L.f.) Jessop & Asparagaceae \\
\hline Muscari commutatum Guss. & Asparagaceae \\
\hline Polygonatum cirrhifolium (Wall.) Royle & Asparagaceae \\
\hline Polygonatum verticillatum (L.) All. & Asparagaceae \\
\hline Sansevieria trifasciata Prain & Asparagaceae \\
\hline Sansevieria roxburghiana Schult. \& Schult.f. & Asparagaceae \\
\hline Impatiens balsamina L. & Balsaminaceae \\
\hline Impatiens racemosa DC. & Balsaminaceae \\
\hline Basella alba L. & Basellaceae \\
\hline Begonia palmata D.Don & Begoniaceae \\
\hline Berberis aristata DC. & Berberidaceae \\
\hline Berberis asiatica Roxb. ex DC. & Berberidaceae \\
\hline Berberis chitria Buch.-Ham. ex Lindl. & Berberidaceae \\
\hline Berberis jaeschkeana C.K.Schneid. & Berberidaceae \\
\hline Berberis wallichiana DC. & Berberidaceae \\
\hline Mahonia napaulensis DC. & Berberidaceae \\
\hline Sinopodophyllum hexandrum (Royle) T.S.Ying & Berberidaceae \\
\hline Dolichandrone falcata (Wall. ex DC.) Seem. & Bignoniaceae \\
\hline Oroxylum indicum (L.) Kurz & Bignoniaceae \\
\hline Spathodea campanulata P.Beauv. & Bignoniaceae \\
\hline Stereospermum chelonoides (L.f.) DC. & Bignoniaceae \\
\hline Tecoma stans (L.) Juss. ex Kunth & Bignoniaceae \\
\hline
\end{tabular}

\begin{tabular}{|c|c|}
\hline Tecomella undulata (Sm.) Seem. & Bignoniaceae \\
\hline Cochlospermum religiosum (L.) Alston & Bixaceae \\
\hline Arnebia benthamii (Wall. ex G.Don) & Boraginaceae \\
\hline Arnebia euchroma (Royle) I.M.Johnst. & Boraginaceae \\
\hline Coldenia procumbens L. & Boraginaceae \\
\hline Cordia dichotoma G.Forst. & Boraginaceae \\
\hline Cordia fragrantissima Kurz & Boraginaceae \\
\hline Cordia grandis Roxb. & Boraginaceae \\
\hline Cordia macleodii Hook.f. \& Thomson & Boraginaceae \\
\hline Cordia monoica Roxb. & Boraginaceae \\
\hline Cordia sinensis Lam. & Boraginaceae \\
\hline Ehretia laevis Roxb. & Boraginaceae \\
\hline Ehretia microphylla Lam. & Boraginaceae \\
\hline Heliotropium bracteatum R.Br. & Boraginaceae \\
\hline Heliotropium indicum L. & Boraginaceae \\
\hline Tournefortia candollei C.B.Clarke & Boraginaceae \\
\hline Tournefortia montana Lour. & Boraginaceae \\
\hline Trichodesma indicum (L.) Lehm. & Boraginaceae \\
\hline Brassica juncea (L.) Czern. & Brassicaceae \\
\hline Cardamine hirsuta L. & Brassicaceae \\
\hline Lepidium sativum $\mathrm{L}$. & Brassicaceae \\
\hline Boswellia serrata Roxb. ex Colebr. & Burseraceae \\
\hline Canarium strictum Roxb. & Burseraceae \\
\hline Commiphora caudata (Wight \& Arn.) Engl. & Burseraceae \\
\hline
\end{tabular}




\section{Ethnobotany Research and Applications}

\begin{tabular}{|c|c|}
\hline Sarcococca pruniformis Lindl. & Buxaceae \\
\hline Cereus hexagonus (L.) Mill. & Cactaceae \\
\hline Cereus pterogonus Lem. & Cactaceae \\
\hline Opuntia stricta (Haw.) Haw. & Cactaceae \\
\hline Mesua ferrea $\mathrm{L}$. & Calophyllacea€ \\
\hline Cannabis sativa L. & Cannabaceae \\
\hline Celtis australis L. & Cannabaceae \\
\hline Celtis tetrandra Roxb. & Cannabaceae \\
\hline Celtis timorensis Span. & Cannabaceae \\
\hline Trema orientalis (L.) Blume & Cannabaceae \\
\hline Canna indica L. & Cannaceae \\
\hline Cadaba fruticosa (L.) Druce & Capparaceae \\
\hline Capparis brevispina DC. & Capparaceae \\
\hline Capparis decidua (Forssk.) Edgew. & Capparaceae \\
\hline Capparis divaricata Lam. & Capparaceae \\
\hline Capparis sepiaria L. & Capparaceae \\
\hline Capparis spinosa L. & Capparaceae \\
\hline Capparis trifoliata Roxb. & Capparaceae \\
\hline Capparis zeylanica L. & Capparaceae \\
\hline Crateva adansonii DC. & Capparaceae \\
\hline Crateva nurvala Buch.-Ham. & Capparaceae \\
\hline Crateva religiosa G. Forst. & Capparaceae \\
\hline Lonicera japonica Thunb. & Caprifoliaceae \\
\hline Valeriana jatamansi Jones & Caprifoliaceae \\
\hline
\end{tabular}

\begin{tabular}{|c|c|}
\hline Carica papaya L. & Caricaceae \\
\hline Drymaria cordata (L.) Willd. ex Schult. & Caryophyllaceae \\
\hline Polycarpaea aurea Wight \& Arn. & Caryophyllaceae \\
\hline Polycarpaea corymbosa (L.) Lam. & Caryophyllaceae \\
\hline Casuarina equisetifolia L. & Casuarinaceae \\
\hline Cassine glauca (Rottb.) Kuntze & Celastraceae \\
\hline Celastrus paniculatus Willd. & Celastraceae \\
\hline Euonymus lawsonii C.B.Clarke ex Prain & Celastraceae \\
\hline Gymnosporia emarginata (Willd.) Thwaites & Celastraceae \\
\hline Gymnosporia heyneana (Roth) M.A.Lawson & Celastraceae \\
\hline Gymnosporia montana (Roth) Benth. & Celastraceae \\
\hline Gymnosporia senegalensis (Lam.) Loes. & Celastraceae \\
\hline Reissantia indica (Willd.) N.Hallé & Celastraceae \\
\hline Calophyllum inophyllum L. & Ciusiaceae \\
\hline Cleome aspera J.Koenig ex DC. & Cleomaceae \\
\hline Cleome gynandra L. & Cleomaceae \\
\hline $\begin{array}{l}\text { Cleome rutidosperma var. burmannii (Wight \& } \\
\text { Arn.) Siddiqui \& S.N.Dixit }\end{array}$ & Cleomaceae \\
\hline Cleome viscosa $\mathrm{L}$. & Cleomaceae \\
\hline Garcinia cowa Roxb. ex Choisy & Clusiaceae \\
\hline Garcinia sopsopia (Buch.-Ham.) Mabb. & Clusiaceae \\
\hline Garcinia spicata Hook.f. & Clusiaceae \\
\hline $\begin{array}{l}\text { Mammea suriga (Buch.-Ham. ex Roxb.) } \\
\text { Kosterm. }\end{array}$ & Clusiaceae \\
\hline Disporum calcaratum D.Don & Colchicaceae \\
\hline
\end{tabular}




\section{Ethnobotany Research and Applications}

\begin{tabular}{|c|c|}
\hline Disporum cantoniense (Lour.) Merr. & Colchicaceae \\
\hline Gloriosa superba L. & Colchicaceae \\
\hline $\begin{array}{l}\text { Anogeissus latifolia (Roxb. ex DC.) Wall. ex } \\
\text { Guillem. \& Perr. }\end{array}$ & Combretaceae \\
\hline Combretum albidum G.Don & Combretaceae \\
\hline Combretum album Pers. & Combretaceae \\
\hline Combretum decandrum Jacq. & Combretaceae \\
\hline Combretum indicum (L.) DeFilipps & Combretaceae \\
\hline Combretum ovalifolium Roxb. & Combretaceae \\
\hline Combretum pilosum Roxb. ex G.Don & Combretaceae \\
\hline Getonia floribunda Roxb. & Combretaceae \\
\hline Terminalia arjuna (Roxb. ex DC.) Wight \& Arn. & Combretaceae \\
\hline Terminalia bellirica (Gaertn.) Roxb. & Combretaceae \\
\hline Terminalia catappa L. & Combretaceae \\
\hline Terminalia chebula Retz. & Combretaceae \\
\hline Terminalia citrina Roxb. ex Fleming & Combretaceae \\
\hline Terminalia cuneata Roth & Combretaceae \\
\hline Terminalia pallida Brandis & Combretaceae \\
\hline Terminalia paniculata Roth & Combretaceae \\
\hline Terminalia tomentosa Wight \& Arn. & Combretaceae \\
\hline Commelina benghalensis $\mathrm{L}$. & Commelinaceae \\
\hline Commelina clavata C.B.Clarke & Commelinaceae \\
\hline Cyanotis axillaris (L.) D.Don ex Sweet & Commelinaceae \\
\hline Cyanotis cristata (L.) D.Don & Commelinaceae \\
\hline
\end{tabular}

\begin{tabular}{|c|c|}
\hline Murdannia pauciflora (G.Brückn.) G.Brückn. & Commelinaceae \\
\hline Acanthospermum hispidum DC. & Compositae \\
\hline Achillea millefolium L. & Compositae \\
\hline Acmella calva (DC.) R.K.Jansen & Compositae \\
\hline Acmella paniculata (Wall. ex DC.) R.K.Jansen & Compositae \\
\hline $\begin{array}{l}\text { Ageratina adenophora (Spreng.) R.M.King \& } \\
\text { H.Rob. }\end{array}$ & Compositae \\
\hline Ageratum conyzoides (L.) L. & Compositae \\
\hline Ainsliaea aptera DC. & Compositae \\
\hline Ainsliaea latifolia (D.Don) Sch.Bip. & Compositae \\
\hline Anaphalis contorta (D.Don) Hook.f. & Compositae \\
\hline Artemisia dracunculus $\mathrm{L}$. & Compositae \\
\hline Artemisia maritima L. & Compositae \\
\hline Artemisia nilagirica (C.B.Clarke) Pamp. & Compositae \\
\hline Artemisia roxburghiana Wall. ex Besser & Compositae \\
\hline Artemisia vulgaris L. & Compositae \\
\hline Bidens biternata (Lour.) Merr. \& Sherff & Compositae \\
\hline Bidens pilosa L. & Compositae \\
\hline Blainvillea acmella (L.) Philipson & Compositae \\
\hline Blumea axillaris (Lam.) DC. & Compositae \\
\hline Blumea hieracifolia Hayata & Compositae \\
\hline Blumea lacera (Burm.f.) DC. & Compositae \\
\hline Chromolaena odorata (L.) R.M.King \& H.Rob. & Compositae \\
\hline Cirsium verutum (D.Don) Spreng. & Compositae \\
\hline
\end{tabular}




\section{Ethnobotany Research and Applications}

\begin{tabular}{|c|c|}
\hline Cirsium wallichii DC. & Compositae \\
\hline Cotula anthemoides $\mathrm{L}$. & Compositae \\
\hline Cyanthillium albicans (DC.) H.Rob. & Compositae \\
\hline Cyanthillium cinereum (L.) H.Rob. & Compositae \\
\hline Dicoma tomentosa Cass. & Compositae \\
\hline Echinops echinatus Roxb. & Compositae \\
\hline Eclipta prostrata (L.) L. & Compositae \\
\hline Elephantopus scaber L. & Compositae \\
\hline Emilia sonchifolia (L.) DC. ex DC. & Compositae \\
\hline Enydra fluctuans DC. & Compositae \\
\hline Erigeron trilobus (Decne.) Boiss. & Compositae \\
\hline Eupatorium cannabinum L. & Compositae \\
\hline Galinsoga parviflora Cav. & Compositae \\
\hline Grangea maderaspatana (L.) Poir. & Compositae \\
\hline Gynura cusimbua (D.Don) S.Moore & Compositae \\
\hline Gynura lycopersicifolia DC. & Compositae \\
\hline Inula cuspidata (Wall. ex DC.) C.B.Clarke & Compositae \\
\hline Jurinea dolomiaea Boiss. & Compositae \\
\hline Lagascea mollis Cav. & Compositae \\
\hline Launaea intybacea (Jacq.) Beauverd & Compositae \\
\hline Mikania micrantha Kunth & Compositae \\
\hline Parthenium hysterophorus L. & Compositae \\
\hline Pentanema indicum (L.) Ling & Compositae \\
\hline Saussurea costus (Falc.) Lipsch. & Compositae \\
\hline
\end{tabular}

\begin{tabular}{ll}
\hline Sonchus oleraceus (L.) L. & Compositae \\
Sphaeranthus indicus L. & Compositae \\
Sphagneticola calendulacea (L.) Pruski & Compositae \\
Spilanthes acmella (L.) L. & Compositae \\
Synedrella nodiflora (L.) Gaertn. & Compositae \\
Tagetes erecta L. & Compositae \\
Taraxacum campylodes G.E.Haglund & Compositae \\
Tridax procumbens (L.) L. & Compositae \\
Xanthium strumarium L. & Compositae \\
Connarus monocarpus L. & Connaraceae \\
Argyreia cuneata Ker Gawl. & Convolvulaceae \\
Argyreia kleiniana Raizada & Convolvulaceae \\
Argyreia nervosa (Burm. f.) Bojer & Convolvulaceae \\
Convolvulus arvensis L. & Convolvulaceae \\
Cuscuta hyalina Roth & Convolvulaceae \\
Cuscuta reflexa Roxb. & Convolvulaceae \\
Evolvulus alsinoides (L.) L. & Convolvulaceae \\
Evolvulus nummularius (L.) L. & Convolvulaceae \\
Ipomoea aquatica Forssk. & Convolvulaceae \\
Ipomoea cairica (L.) Sweet & Convolvulaceae \\
Ipomoea cheirophylla O'Donell & Convolvulaceae \\
Ipomoea hederifolia L. & Convolvulaceae \\
Ipomoea marginata (Desr.) Verdc. & Convolvulaceae \\
Ipomoea mauritiana Jacq. & Convolvulaceae \\
\hline &
\end{tabular}




\section{Ethnobotany Research and Applications}

\begin{tabular}{|c|c|}
\hline Ipomoea nil (L.) Roth & Convolvulaceae \\
\hline Ipomoea obscura (L.) Ker Gawl. & Convolvulaceae \\
\hline Ipomoea obtusata Griseb. & Convolvulaceae \\
\hline Ipomoea pes-tigridis L. & Convolvulaceae \\
\hline Ipomoea sumatrana (Miq.) Ooststr. & Convolvulaceae \\
\hline Merremia emarginata (Burm. f.) Hallier f. & Convolvulaceae \\
\hline Merremia tridentata (L.) Hallier f. & Convolvulaceae \\
\hline Merremia vitifolia (Burm. f.) Hallier f. & Convolvulaceae \\
\hline Operculina turpethum (L.) Silva Manso & Convolvulaceae \\
\hline Rivea hypocrateriformis Choisy & Convolvulaceae \\
\hline Coriaria nepalensis Wall. & Coriariaceae \\
\hline Alangium salviifolium (L.f.) Wangerin & Cornaceae \\
\hline Alangium chinense (Lour.) Harms & Cornaceae \\
\hline Cornus capitata Wall. & Cornaceae \\
\hline Cornus macrophylla Wall. & Cornaceae \\
\hline Cornus oblonga Wall. & Cornaceae \\
\hline Cheilocostus speciosus (J.Koenig) & Costaceae \\
\hline Bryophyllum pinnatum (Lam.) Oken & Crassulaceae \\
\hline $\begin{array}{l}\text { Rhodiola heterodonta (Hook. f. \& Thomson) } \\
\text { Boriss. }\end{array}$ & Crassulaceae \\
\hline Cayaponia laciniosa (L.) C.Jeffrey & Cucurbitaceae \\
\hline Citrullus colocynthis (L.) Schrad. & Cucurbitaceae \\
\hline Coccinia grandis (L.) Voigt & Cucurbitaceae \\
\hline Corallocarpus epigaeus (Rottler) Hook.f. & Cucurbitaceae \\
\hline
\end{tabular}

\begin{tabular}{ll}
\hline Cucumis melo L. & Cucurbitaceae \\
Cucumis sativus L. & Cucurbitaceae \\
Diplocyclos palmatus (L.) C.Jeffrey & Cucurbitaceae \\
Hodgsonia macrocarpa (Blume) Cogn. & Cucurbitaceae \\
Lagenaria siceraria (Molina) Standl. & Cucurbitaceae \\
Luffa cylindrica (L.) M.Roem. & Cucurbitaceae \\
Momordica charantia L. & Cucurbitaceae \\
Momordica dioica Roxb. ex Willd. & Cucurbitaceae \\
Mukia maderaspatana (L.) M.Roem. & Cucurbitaceae \\
Solena amplexicaulis (Lam.) Gandhi & Cucurbitaceae \\
Trichosanthes cucumerina L. & Cucurbitaceae \\
Trichosanthes tricuspidata Lour. & Cucurbitaceae \\
Bulbostylis barbata (Rottb.) C.B.Clarke & Cyperaceae \\
Cyperus compressus L. & Cyperaceae \\
Cyperus difformis L. & Cyperaceae \\
Cyperus rotundus L. & Cyperaceae \\
Cyperus scariosus R.Br. & Cyperaceae \\
Fimbristylis aestivalis Vahl & Cyperaceae \\
Fimbristylis dichotoma (L.) Vahl & Cyperaceae \\
Hypolytrum nemorum (Vahl) Spreng. & Cyperaceae \\
Rhynchospora colorata (L.) H.Pfeiff. & Cyperaceae \\
Dillenia indica L. & Dilleniaceae \\
Dillenia pentagyna Roxb. & Dilleniaceae \\
Dioscorea alata L. & Dioscoreaceae \\
\hline &
\end{tabular}




\section{Ethnobotany Research and Applications}

\begin{tabular}{|c|c|}
\hline Dioscorea bulbifera L. & Dioscoreaceae \\
\hline Dioscorea deltoidea Wall. ex Griseb. & Dioscoreaceae \\
\hline Dioscorea hispida Dennst. & Dioscoreaceae \\
\hline Dioscorea oppositiflora Griseb. & Dioscoreaceae \\
\hline Dioscorea pentaphylla L. & Dioscoreaceae \\
\hline Dioscorea pubera Blume & Dioscoreaceae \\
\hline Dioscorea wallichii Hook.f. & Dioscoreaceae \\
\hline Tacca leontopetaloides (L.) Kuntze & Dioscoreaceae \\
\hline Hopea parviflora Bedd. & Dipterocarpaceae \\
\hline Shorea robusta Gaertn. & Dipterocarpaceae \\
\hline Shorea roxburghii G.Don & Dipterocarpaceae \\
\hline Shorea tumbuggaia Roxb. & Dipterocarpaceae \\
\hline Vateria indica $\mathrm{L}$. & Dipterocarpaceae \\
\hline Diospyros ebenum J.Koenig ex Retz. & Ebenaceae \\
\hline Diospyros malabarica (Desr.) Kostel. & Ebenaceae \\
\hline Diospyros melanoxylon Roxb. & Ebenaceae \\
\hline Diospyros montana Roxb. & Ebenaceae \\
\hline Diospyros pilosiuscula G.Don & Ebenaceae \\
\hline Diospyros vera (Lour.) A.Chev. & Ebenaceae \\
\hline Elaeagnus rhamnoides (L.) A.Nelson & Elaeagnaceae \\
\hline Hippophae salicifolia D.Don & Elaeagnaceae \\
\hline Elaeocarpus tuberculatus Roxb. & Elaeocarpaceae \\
\hline Agapetes auriculata (Griff.) Benth. \& Hook.f. & Ericaceae \\
\hline Agapetes variegata (Roxb.) D.Don ex G.Don & Ericaceae \\
\hline
\end{tabular}

\begin{tabular}{|c|c|}
\hline Gaultheria fragrantissima Wall. & Ericaceae \\
\hline Lyonia ovalifolia (Wall.) Drude & Ericaceae \\
\hline Rhododendron lepidotum Wall. ex G. Don & Ericaceae \\
\hline Rhododendron anthopogon D. Don & Ericaceae \\
\hline Rhododendron arboreum Sm. & Ericaceae \\
\hline Rhododendron campanulatum D. Don & Ericaceae \\
\hline Erythroxylum kunthianum Kurz & Erythroxylaceae \\
\hline Erythroxylum monogynum Roxb. & Erythroxylaceae \\
\hline Acalypha alnifolia Klein ex Willd. & Euphorbiaceae \\
\hline Acalypha fruticosa Forssk. & Euphorbiaceae \\
\hline Acalypha indica L. & Euphorbiaceae \\
\hline Croton bonplandianus Baill. & Euphorbiaceae \\
\hline Croton caudatus Geiseler & Euphorbiaceae \\
\hline Euphorbia antiquorum L. & Euphorbiaceae \\
\hline Euphorbia fusiformis Buch.-Ham. ex D.Don & Euphorbiaceae \\
\hline Euphorbia hirta L. & Euphorbiaceae \\
\hline Euphorbia indica Lam. & Euphorbiaceae \\
\hline Euphorbia neriifolia L. & Euphorbiaceae \\
\hline Euphorbia pilosa L. & Euphorbiaceae \\
\hline Euphorbia tirucalli L. & Euphorbiaceae \\
\hline Euphorbia tortilis Rottler ex Ainslie & Euphorbiaceae \\
\hline Euphorbia trigona Mill. & Euphorbiaceae \\
\hline Excoecaria agallocha L. & Euphorbiaceae \\
\hline Givotia moluccana (L.) Sreem. & Euphorbiaceae \\
\hline
\end{tabular}




\section{Ethnobotany Research and Applications}

\begin{tabular}{|c|c|}
\hline Hevea brasiliensis (Willd. ex A.Juss.) & Euphorbiaceae \\
\hline Homonoia riparia Lour. & Euphorbiaceae \\
\hline Jatropha curcas L. & Euphorbiaceae \\
\hline Jatropha glandulifera Roxb. & Euphorbiaceae \\
\hline Jatropha gossypiifolia L. & Euphorbiaceae \\
\hline Macaranga peltata (Roxb.) Müll.Arg. & Euphorbiaceae \\
\hline Mallotus philippensis (Lam.) Müll.Arg. & Euphorbiaceae \\
\hline Mallotus repandus (Willd.) Müll.Arg. & Euphorbiaceae \\
\hline Microstachys chamaelea (L.) Müll.Arg. & Euphorbiaceae \\
\hline Ricinus communis L. & Euphorbiaceae \\
\hline Tragia involucrata $\mathrm{L}$. & Euphorbiaceae \\
\hline Tragia plukenetii Radcl.-Sm. & Euphorbiaceae \\
\hline Quercus oblongata D.Don & Fagaceae \\
\hline Quercus semecarpifolia Sm. & Fagaceae \\
\hline Quercus serrata Murray & Fagaceae \\
\hline Canscora alata (Roth) Wall. & Gentianaceae \\
\hline $\begin{array}{l}\text { Canscora diffusa (Vahl) R.Br. ex Roem. \& } \\
\text { Schult. }\end{array}$ & Gentianaceae \\
\hline Enicostema axillare (Poir. ex Lam.) A.Raynal & Gentianaceae \\
\hline Gentiana kurroo Royle & Gentianaceae \\
\hline Swertia angustifolia Buch.-Ham. ex D. Don & Gentianaceae \\
\hline $\begin{array}{l}\text { Swertia chirayita (Roxb.) Buch.-Ham. ex } \\
\text { C.B.Clarke }\end{array}$ & Gentianaceae \\
\hline Swertia cordata (Wall. ex G. Don) C.B. Clarke & Gentianaceae \\
\hline Geranium mascatense Boiss. & Geraniaceae \\
\hline
\end{tabular}

\begin{tabular}{|c|c|}
\hline Geranium wallichianum D.Don ex Sweet & Geraniaceae \\
\hline Aeschynanthus superbus C.B.Clarke & Gesneriaceae \\
\hline Aeschynomene aspera L. & Gesneriaceae \\
\hline Corylopsis himalayana Griff. & Hamamelidaceae \\
\hline Gyrocarpus americanus Jacq. & Hernandiaceae \\
\hline Hypericum oblongifolium Choisy & Hypericaceae \\
\hline Curculigo orchioides Gaertn. & Hypoxidaceae \\
\hline Nothapodytes nimmoniana (J.Graham) Mabb. & Icacinaceae \\
\hline Engelhardtia spicata Lechen ex Blume & Juglandaceae \\
\hline Juglans regia L. & Juglandaceae \\
\hline Ajuga integrifolia Buch.-Ham. & Lamiaceae \\
\hline Anisochilus carnosus (L.f.) Wall. & Lamiaceae \\
\hline Anisomeles indica (L.) Kuntze & Lamiaceae \\
\hline Anisomeles malabarica (L.) R.Br. ex Sims & Lamiaceae \\
\hline Basilicum polystachyon (L.) Moench & Lamiaceae \\
\hline Callicarpa arborea Roxb. & Lamiaceae \\
\hline Callicarpa macrophylla Vahl & Lamiaceae \\
\hline Clerodendrum chinense (Osbeck) Mabb. & Lamiaceae \\
\hline Clerodendrum cordatum D.Don & Lamiaceae \\
\hline Clerodendrum infortunatum $L$. & Lamiaceae \\
\hline Clerodendrum paniculatum $L$. & Lamiaceae \\
\hline Clerodendrum phlomidis L.f. & Lamiaceae \\
\hline Clerodendrum volubile P.Beauv. & Lamiaceae \\
\hline Colebrookea oppositifolia Sm. & Lamiaceae \\
\hline
\end{tabular}




\section{Ethnobotany Research and Applications}

\begin{tabular}{|c|c|}
\hline Gmelina arborea Roxb. & Lamiaceae \\
\hline Gmelina asiatica $L$. & Lamiaceae \\
\hline Hyptis suaveolens (L.) Poit. & Lamiaceae \\
\hline Hyssopus officinalis $L$. & Lamiaceae \\
\hline Lavandula bipinnata (Roth) Kuntze & Lamiaceae \\
\hline Leonotis nepetifolia (L.) R.Br. & Lamiaceae \\
\hline Leonurus sibiricus $L$. & Lamiaceae \\
\hline Leucas aspera (Willd.) Link & Lamiaceae \\
\hline Leucas biflora (Vahl) Sm. & Lamiaceae \\
\hline Leucas cephalotes (Roth) Spreng. & Lamiaceae \\
\hline Leucas lanata Benth. & Lamiaceae \\
\hline Leucas zeylanica (L.) W.T.Aiton & Lamiaceae \\
\hline Mentha arvensis $L$. & Lamiaceae \\
\hline Ocimum americanum $L$. & Lamiaceae \\
\hline Ocimum basilicum $L$. & Lamiaceae \\
\hline Ocimum gratissimum $L$. & Lamiaceae \\
\hline Ocimum tenuiflorum $L$. & Lamiaceae \\
\hline Origanum vulgare $L$. & Lamiaceae \\
\hline Orthosiphon thymiflorus (Roth) Sleesen & Lamiaceae \\
\hline Pogostemon myosuroides (Roth) Kuntze & Lamiaceae \\
\hline Pogostemon parviflorus Benth. & Lamiaceae \\
\hline Pogostemon purpurascens Dalzell & Lamiaceae \\
\hline Pogostemon quadrifolius (Benth.) F.Muell. & Lamiaceae \\
\hline Premna mollissima Roth & Lamiaceae \\
\hline
\end{tabular}

\begin{tabular}{|c|c|}
\hline Premna serratifolia $L$. & Lamiaceae \\
\hline Premna tomentosa Willd. & Lamiaceae \\
\hline Rotheca serrata (L.) Steane \& Mabb. & Lamiaceae \\
\hline Salvia nubicola Wall. ex Sweet & Lamiaceae \\
\hline Scutellaria discolor Colebr. & Lamiaceae \\
\hline Symphorema involucratum Roxb. & Lamiaceae \\
\hline Symphorema polyandrum Wight & Lamiaceae \\
\hline Tectona grandis L.f. & Lamiaceae \\
\hline Thymus mongolicus (Ronniger) Ronniger & Lamiaceae \\
\hline Thymus vulgaris $L$. & Lamiaceae \\
\hline Vitex altissima L.f. & Lamiaceae \\
\hline Vitex leucoxylon L.f. & Lamiaceae \\
\hline Vitex negundo $L$. & Lamiaceae \\
\hline Vitex parviflora A.Juss. & Lamiaceae \\
\hline Vitex trifolia $L$. & Lamiaceae \\
\hline Volkameria inermis $L$. & Lamiaceae \\
\hline Actinodaphne madraspatana Bedd. ex Hook.f. & Lauraceae \\
\hline Alseodaphne semecarpifolia Nees & Lauraceae \\
\hline Cassytha filiformis $L$. & Lauraceae \\
\hline Cinnamomum curvifolium (Lam.) Nees & Lauraceae \\
\hline Cinnamomum glanduliferum (Wall.) Meisn. & Lauraceae \\
\hline $\begin{array}{l}\text { Cinnamomum tamala (Buch.-Ham.) T.Nees \& } \\
\text { Eberm. }\end{array}$ & Lauraceae \\
\hline Cinnamomum verum J.Presl & Lauraceae \\
\hline
\end{tabular}




\section{Ethnobotany Research and Applications}

\begin{tabular}{|c|c|}
\hline Cryptocarya amygdalina Nees & Lauraceae \\
\hline Lindera latifolia Hook. $f$. & Lauraceae \\
\hline Lindera pulcherrima (Nees) Hook. $f$. & Lauraceae \\
\hline Litsea cubeba (Lour.) Pers. & Lauraceae \\
\hline Litsea glutinosa (Lour.) C.B.Rob. & Lauraceae \\
\hline Litsea monopetala (Roxb.) Pers. & Lauraceae \\
\hline Litsea salicifolia (J. Roxb. ex Nees) Hook. f. & Lauraceae \\
\hline Machilus duthiei King & Lauraceae \\
\hline Machilus gamblei King ex Hook. $f$. & Lauraceae \\
\hline Persea gamblei (King ex Hook. f.) Kosterm. & Lauraceae \\
\hline Phoebe attenuata (Nees) Nees & Lauraceae \\
\hline Barringtonia acutangula (L.) Gaertn. & Lecythidaceae \\
\hline Careya arborea Roxb. & Lecythidaceae \\
\hline Careya herbacea Roxb. & Lecythidaceae \\
\hline Couroupita guianensis Aubl. & Lecythidaceae \\
\hline Abrus precatorius $L$. & Leguminosae \\
\hline Abrus pulchellus Thwaites & Leguminosae \\
\hline Acacia caesia (L.) Willd. & Leguminosae \\
\hline Acacia catechu (L.f.) Willd. & Leguminosae \\
\hline Acacia chundra (Rottler) Willd. & Leguminosae \\
\hline Acacia farnesiana (L.) Willd. & Leguminosae \\
\hline Acacia ferruginea $D C$. & Leguminosae \\
\hline Acacia intsia (L.) Willd. & Leguminosae \\
\hline Acacia leucophloea (Roxb.) Willd. & Leguminosae \\
\hline
\end{tabular}

\begin{tabular}{|c|c|}
\hline Acacia nilotica (L.) Delile & Leguminosae \\
\hline Acacia polyacantha Willd. & Leguminosae \\
\hline Acacia sinuata (Lour.) Merr. & Leguminosae \\
\hline Acacia torta (Roxb.) Craib & Leguminosae \\
\hline Adenanthera pavonina $L$. & Leguminosae \\
\hline Albizia amara (Roxb.) B.Boivin & Leguminosae \\
\hline Albizia chinensis (Osbeck) Merr. & Leguminosae \\
\hline Albizia lebbeck (L.) Benth. & Leguminosae \\
\hline Albizia odoratissima (L.f.) Benth. & Leguminosae \\
\hline Albizia procera (Roxb.) Benth. & Leguminosae \\
\hline Alysicarpus monilifer (L.) DC. & Leguminosae \\
\hline Astragalus rhizanthus Benth. & Leguminosae \\
\hline Bauhinia acuminata $L$. & Leguminosae \\
\hline Bauhinia malabarica Roxb. & Leguminosae \\
\hline Bauhinia purpurea $L$. & Leguminosae \\
\hline Bauhinia racemosa Lam. & Leguminosae \\
\hline Bauhinia vahlii Wight \& Arn. & Leguminosae \\
\hline Bauhinia variegata $L$. & Leguminosae \\
\hline Butea monosperma (Lam.) Taub. & Leguminosae \\
\hline Butea superba Roxb. & Leguminosae \\
\hline Caesalpinia bonduc (L.) Roxb. & Leguminosae \\
\hline Caesalpinia crista $L$. & Leguminosae \\
\hline Caesalpinia decapetala (Roth) Alston & Leguminosae \\
\hline Caesalpinia globulorum Bakh.f. \& P.Royen & Leguminosae \\
\hline
\end{tabular}




\section{Ethnobotany Research and Applications}

\begin{tabular}{|c|c|}
\hline Caesalpinia pulcherrima (L.) Sw. & Leguminosae \\
\hline Cajanus cajan (L.) Millsp. & Leguminosae \\
\hline Cajanus crassus (King) Maesen & Leguminosae \\
\hline Cajanus scarabaeoides (L.) Thouars & Leguminosae \\
\hline Cassia bakeriana Craib & Leguminosae \\
\hline Cassia fistula $L$. & Leguminosae \\
\hline Senna montana (Roth) V.Singh & Leguminosae \\
\hline Centrosema coriaceum Benth. & Leguminosae \\
\hline Chamaecrista absus (L.) H.S.Irwin \& Barneby & Leguminosae \\
\hline Chamaecrista mimosoides (L.) Greene & Leguminosae \\
\hline Clitoria ternatea $L$. & Leguminosae \\
\hline Codariocalyx motorius (Houtt.) H.Ohashi & Leguminosae \\
\hline Crotalaria albida Roth & Leguminosae \\
\hline Crotalaria pallida Aiton & Leguminosae \\
\hline Crotalaria prostrata Willd. & Leguminosae \\
\hline Crotalaria ramosissima Roxb. & Leguminosae \\
\hline Crotalaria retusa $L$. & Leguminosae \\
\hline Crotalaria spectabilis Roth & Leguminosae \\
\hline Crotalaria verrucosa $L$. & Leguminosae \\
\hline Cullen corylifolium (L.) Medik. & Leguminosae \\
\hline Dalbergia candenatensis (Dennst.) Prain & Leguminosae \\
\hline Dalbergia lanceolaria L.f. & Leguminosae \\
\hline $\begin{array}{l}\text { Dalbergia lanceolaria subsp. paniculata (Roxb.) } \\
\text { Thoth }\end{array}$ & Leguminosae \\
\hline
\end{tabular}

\begin{tabular}{|c|c|}
\hline Dalbergia latifolia Roxb. & Leguminosae \\
\hline Dalbergia sissoo DC. & Leguminosae \\
\hline Delonix elata (L.) Gamble & Leguminosae \\
\hline Delonix regia (Hook.) Raf. & Leguminosae \\
\hline Derris scandens (Roxb.) Benth. & Leguminosae \\
\hline Desmodium elegans $D C$. & Leguminosae \\
\hline Desmodium gangeticum (L.) DC. & Leguminosae \\
\hline Desmodium heterocarpon (L.) DC. & Leguminosae \\
\hline Desmodium oojeinense (Roxb.) H.Ohashi & Leguminosae \\
\hline Desmodium scorpiurus (Sw.) Desv. & Leguminosae \\
\hline Desmodium triflorum (L.) DC. & Leguminosae \\
\hline Dichrostachys cinerea (L.) Wight \& Arn. & Leguminosae \\
\hline Entada gigas (L.) Fawc. \& Rendle & Leguminosae \\
\hline Entada phaseoloides (L.) Merr. & Leguminosae \\
\hline Entada rheedii Spreng. & Leguminosae \\
\hline Eriosema himalaicum H.Ohashi & Leguminosae \\
\hline Erythrina stricta Roxb. & Leguminosae \\
\hline Erythrina suberosa Roxb. & Leguminosae \\
\hline Erythrina variegata $L$. & Leguminosae \\
\hline Flemingia macrophylla (Willd.) Merr. & Leguminosae \\
\hline Flemingia semialata Roxb. & Leguminosae \\
\hline Flemingia strobilifera (L.) W.T.Aiton & Leguminosae \\
\hline Gliricidia sepium (Jacq.) Walp. & Leguminosae \\
\hline Indigofera aspalathoides DC. & Leguminosae \\
\hline
\end{tabular}




\section{Ethnobotany Research and Applications}

\begin{tabular}{|c|c|}
\hline Indigofera endecaphylla Jacq. ex Poir. & Leguminosae \\
\hline Indigofera hirsuta $L$. & Leguminosae \\
\hline Indigofera linnaei Ali & Leguminosae \\
\hline Indigofera mysorensis DC. & Leguminosae \\
\hline Indigofera oblongifolia Forssk. & Leguminosae \\
\hline Indigofera tinctoria $\mathrm{L}$. & Leguminosae \\
\hline Indigofera trita L.f. & Leguminosae \\
\hline Kingiodendron pinnatum (DC.) Harms & Leguminosae \\
\hline Leucaena leucocephala (Lam.) de Wit & Leguminosae \\
\hline Mimosa hamata Willd. & Leguminosae \\
\hline Mimosa pudica L. & Leguminosae \\
\hline Mimosa rubicaulis Lam. & Leguminosae \\
\hline Mucuna gigantea (Willd.) DC. & Leguminosae \\
\hline Mucuna pruriens (L.) DC. & Leguminosae \\
\hline Parkia timoriana (DC.) Merr. & Leguminosae \\
\hline Peltophorum pterocarpum (DC.) K.Heyne & Leguminosae \\
\hline Pithecellobium dulce (Roxb.) Benth. & Leguminosae \\
\hline Pongamia pinnata (L.) Pierre & Leguminosae \\
\hline Prosopis chilensis (Molina) Stuntz & Leguminosae \\
\hline Prosopis cineraria (L.) Druce & Leguminosae \\
\hline Pseudarthria viscida (L.) Wight \& Arn. & Leguminosae \\
\hline Pterocarpus marsupium Roxb. & Leguminosae \\
\hline $\begin{array}{l}\text { Pterolobium hexapetalum (Roth) Santapau \& } \\
\text { Wagh }\end{array}$ & Leguminosae \\
\hline
\end{tabular}

Pueraria phaseoloides (Roxb.) Benth.

Pueraria tuberosa (Willd.) DC.

Rhynchosia beddomei Baker

Rhynchosia cana (Willd.) DC.

Rhynchosia minima (L.) DC.

Saraca asoca (Roxb.) Willd.

Saraca indica L.

Senna alata (L.) Roxb.

Senna alexandrina Mill.

Senna auriculata (L.) Roxb.

Senna occidentalis (L.) Link

Senna siamea (Lam.) H.S.Irwin \& Barneby

Senna sophera (L.) Roxb.

Senna tora (L.) Roxb.

Sesbania grandiflora (L.) Pers.

Sesbania sesban (L.) Merr.

Tadehagi triquetrum (L.) H.Ohashi

Tamarindus indica L.

Tephrosia purpurea (L.) Pers.

Tephrosia tinctoria Pers.

Tephrosia villosa (L.) Pers.

Teramnus labialis (L.f.) Spreng.

Trigonella foenum-graecum L.

Uraria lagopodoides (L.) DC.
Leguminosae

Leguminosae

Leguminosae

Leguminosae

Leguminosae

Leguminosae

Leguminosae

Leguminosae

Leguminosae

Leguminosae

Leguminosae

Leguminosae

Leguminosae

Leguminosae

Leguminosae

Leguminosae

Leguminosae

Leguminosae

Leguminosae

Leguminosae

Leguminosae

Leguminosae

Leguminosae

Leguminosae 


\section{Ethnobotany Research and Applications}

\begin{tabular}{ll}
\hline Uraria picta (Jacq.) DC. & Leguminosae \\
Vigna aconitifolia (Jacq.) Marechal & Leguminosae \\
Vigna radiata (L.) R.Wilczek & Leguminosae \\
Zornia diphylla (L.) Pers. & Leguminosae \\
Zornia gibbosa Span. & Leguminosae \\
Fritillaria cirrhosa D.Don & Liliaceae \\
Hugonia serrata Lam. & Linaceae \\
Reinwardtia indica Dumort. & Linaceae \\
Lindernia ciliata (Colsm.) Pennell & Linderniaceae \\
Lindernia crustacea (L.) F.Muell. & Linderniaceae \\
Mitreola petiolata (J.F.Gmel.) Torr. \& A.Gray & Loganiaceae \\
Spigelia anthelmia L. & Loganiaceae \\
Strychnos colubrina L. & Loganiaceae \\
Strychnos dalzellii C.B.Clarke & Loganiaceae \\
Strychnos nux-vomica L. & Lythraceae \\
Strychnos potatorum L.f. & Lythraceae \\
Dendrophthoe falcata (L.f.) Ettingsh. & Loganiaceae \\
Helixanthera ligustrina (Wall.) Danser & Loranthaceae \\
Loranthus longiflorus Desr. & Loranthaceae \\
Tamillus tomentosus Tiegh. & Logeaceae \\
\hline
\end{tabular}

\begin{tabular}{|c|c|}
\hline Punica granatum L. & Lythraceae \\
\hline Woodfordia fruticosa (L.) Kurz & Lythraceae \\
\hline Magnolia champaca (L.) Baill. ex Pierre & Magnoliaceae \\
\hline Hiptage benghalensis (L.) Kurz & Malpighiaceae \\
\hline Abelmoschus manihot (L.) Medik. & Malvaceae \\
\hline Abroma augusta (L.) L.f. & Malvaceae \\
\hline Abutilon indicum (L.) Sweet & Malvaceae \\
\hline Abutilon pannosum (G.Forst.) Schltdl. & Malvaceae \\
\hline Bombax ceiba L. & Malvaceae \\
\hline Byttneria herbacea Roxb. & Malvaceae \\
\hline Ceiba pentandra (L.) Gaertn. & Malvaceae \\
\hline Corchorus aestuans L. & Malvaceae \\
\hline Corchorus capsularis L. & Malvaceae \\
\hline Corchorus trilocularis $\mathrm{L}$. & Malvaceae \\
\hline Firmiana simplex (L.) W.Wight & Malvaceae \\
\hline Grewia carpinifolia Juss. & Malvaceae \\
\hline Grewia flavescens Juss. & Malvaceae \\
\hline Grewia hirsuta Vahl & Malvaceae \\
\hline Grewia multiflora Juss. & Malvaceae \\
\hline Grewia nervosa (Lour.) Panigrahi & Malvaceae \\
\hline Grewia optiva J.R.Drumm. ex Burret & Malvaceae \\
\hline Grewia tiliifolia Vahl & Malvaceae \\
\hline Guazuma ulmifolia Lam. & Malvaceae \\
\hline Helicteres isora L. & Malvaceae \\
\hline
\end{tabular}




\section{Ethnobotany Research and Applications}

\begin{tabular}{|c|c|}
\hline Herissantia crispa (L.) Brizicky & Malvaceae \\
\hline Hibiscus hispidissimus Griff. & Malvaceae \\
\hline Hibiscus mutabilis L. & Malvaceae \\
\hline Hibiscus rosa-sinensis $\mathrm{L}$. & Malvaceae \\
\hline Hibiscus sabdariffa L. & Malvaceae \\
\hline Hibiscus vitifolius $\mathrm{L}$. & Malvaceae \\
\hline Kleinhovia hospita L. & Malvaceae \\
\hline Kydia calycina Roxb. & Malvaceae \\
\hline Melochia corchorifolia L. & Malvaceae \\
\hline Pavonia zeylanica (L.) Cav. & Malvaceae \\
\hline Pterospermum acerifolium (L.) Willd. & Malvaceae \\
\hline Pterospermum canescens Roxb. & Malvaceae \\
\hline $\begin{array}{l}\text { Pterospermum xylocarpum (Gaertn.) Santapau \& } \\
\text { Wagh }\end{array}$ & Malvaceae \\
\hline Sida acuta Burm.f. & Malvaceae \\
\hline Sida cordata (Burm.f.) Borss.Waalk. & Malvaceae \\
\hline Sida cordifolia L. & Malvaceae \\
\hline Sida rhombifolia L. & Malvaceae \\
\hline Sterculia coccinea Roxb. & Malvaceae \\
\hline Sterculia guttata Roxb. ex G.Don & Malvaceae \\
\hline Sterculia villosa Roxb. & Malvaceae \\
\hline Thespesia lampas (Cav.) Dalzell & Malvaceae \\
\hline Thespesia populnea (L.) Sol. ex Corrêa & Malvaceae \\
\hline Triumfetta pilosa Roth & Malvaceae \\
\hline
\end{tabular}

\begin{tabular}{|c|c|}
\hline Triumfetta rhomboidea Jacq. & Malvaceae \\
\hline Triumfetta rotundifolia Lam. & Malvaceae \\
\hline Urena lobata L. & Malvaceae \\
\hline Waltheria indica $\mathrm{L}$. & Malvaceae \\
\hline Manilkara hexandra (Roxb.) Dubard & Martyniaceae \\
\hline Martynia annua L. & Martyniaceae \\
\hline Paris polyphylla Sm. & Melanthiaceae \\
\hline Melastoma malabathricum L. & Melastomataceae \\
\hline Memecylon edule Roxb. & Melastomataceae \\
\hline $\begin{array}{l}\text { Memecylon randerianum S.M.Almeida \& } \\
\text { M.R.Almeida }\end{array}$ & Melastomataceae \\
\hline Memecylon umbellatum Burm. $\mathrm{f}$. & Melastomataceae \\
\hline Osbeckia capitata Benth. ex Naudin & Melastomataceae \\
\hline Osbeckia chinensis L. & Melastomataceae \\
\hline Osbeckia muralis Naudin & Melastomataceae \\
\hline Osbeckia stellata Buch.-Ham. ex Ker Gawl. & Melastomataceae \\
\hline Aglaia elaeagnoidea (A.Juss.) Benth. & Meliaceae \\
\hline Aphanamixis polystachya (Wall.) R.Parker & Meliaceae \\
\hline Azadirachta indica A.Juss. & Meliaceae \\
\hline Chukrasia tabularis A.Juss. & Meliaceae \\
\hline Cipadessa baccifera (Roth) Miq. & Meliaceae \\
\hline Dysoxylum excelsum Blume & Meliaceae \\
\hline Dysoxylum gotadhora (Buch.-Ham.) Mabb. & Meliaceae \\
\hline Dysoxylum mollissimum Blume & Meliaceae \\
\hline
\end{tabular}




\section{Ethnobotany Research and Applications}

\begin{tabular}{|c|c|}
\hline Melia azedarach L. & Meliaceae \\
\hline Naregamia alata Wight \& Arn. & Meliaceae \\
\hline Soymida febrifuga (Roxb.) A. Juss. & Meliaceae \\
\hline Toona ciliata M.Roem. & Meliaceae \\
\hline Cissampelos pareira $\mathrm{L}$. & Menispermaceae \\
\hline Cocculus hirsutus (L.) W. Theob & Menispermaceae \\
\hline Cyclea peltata (Lam.) Hook.f. \& Thomson & Menispermaceae \\
\hline Pachygone ovata (Poir.) Diels & Menispermaceae \\
\hline Pericampylus glaucus (Lam.) Merr. & Menispermaceae \\
\hline Stephania hernandiifolia (Willd.) Walp. & Menispermaceae \\
\hline Stephania japonica (Thunb.) Miers & Menispermaceae \\
\hline Stephania glabra (Roxb.) Miers & Menispermaceae \\
\hline Tiliacora racemosa Colebr. & Menispermaceae \\
\hline Tinospora sinensis (Lour.) Merr. & Menispermaceae \\
\hline Glinus oppositifolius (L.) Aug.DC. & Molluginaceae \\
\hline Mollugo pentaphylla L. & Molluginaceae \\
\hline Antiaris toxicaria Lesch. & Moraceae \\
\hline Artocarpus heterophyllus Lam. & Moraceae \\
\hline Artocarpus hirsutus Lam. & Moraceae \\
\hline Artocarpus rigidus Blume & Moraceae \\
\hline Artocarpus lacucha Buch.-Ham. & Moraceae \\
\hline Ficus amplissima Sm. & Moraceae \\
\hline Ficus arnottiana (Miq.) Miq. & Moraceae \\
\hline Ficus auriculata Lour. & Moraceae \\
\hline
\end{tabular}

\begin{tabular}{ll}
\hline Ficus benghalensis L. & Moraceae \\
Ficus benjamina L. & Moraceae \\
Ficus hispida L.f. & Moraceae \\
Ficus microcarpa L.f. & Moraceae \\
Ficus mollis Vahl & Moraceae \\
Ficus nervosa B.Heyne ex Roth & Moraceae \\
Ficus palmata Forssk. & Moraceae \\
Ficus racemosa L. & Moraceae \\
Ficus religiosa L. & Moraceae \\
Ficus semicordata Buch.-Ham. ex Sm. & Moraceae \\
Ficus virens Aiton & Moraceae \\
Morus alba L. & Moraceae \\
Plecospermum spinosum Trécul & Moraceae \\
Streblus asper Lour. & Moraceae \\
Moringa concanensis Nimmo & Moringaceae \\
Moringa oleifera Lam. & Moringaceae \\
Ensete superbum (Roxb.) Cheesman & Musaceae \\
Musa acuminata Colla & Musaceae \\
Musa balbisiana Colla & Musaceae \\
Musa x paradisiaca L. & Musaceae \\
Myrcia bracteata (Rich.) DC. & Myricaceae \\
Myrica esculenta Buch.-Ham. ex D. Don & Myricaceae \\
Knema attenuata Warb. & Myristicaceae \\
Knema latifolia Warb. & Myristicaceae \\
\hline & \\
\hline
\end{tabular}




\section{Ethnobotany Research and Applications}

\begin{tabular}{|c|c|}
\hline Myristica beddomei King & Myristicaceae \\
\hline Myristica fragrans Houtt. & Myristicaceae \\
\hline Myristica malabarica Lam. & Myristicaceae \\
\hline $\begin{array}{l}\text { Corymbia citriodora (Hook.) K.D.Hill \& } \\
\text { L.A.S.Johnson }\end{array}$ & Myrtaceae \\
\hline $\begin{array}{l}\text { Corymbia maculata (Hook.) K.D.Hill \& } \\
\text { L.A.S.Johnson }\end{array}$ & Myrtaceae \\
\hline Eucalyptus globulus Labill. & Myrtaceae \\
\hline Eucalyptus tereticornis Sm. & Myrtaceae \\
\hline Psidium guajava L. & Myrtaceae \\
\hline Syzygium alternifolium (Wight) Walp. & Myrtaceae \\
\hline Syzygium caryophyllatum (L.) Alston & Myrtaceae \\
\hline Syzygium cumini (L.) Skeels & Myrtaceae \\
\hline Syzygium formosum (Wall.) Masam. & Myrtaceae \\
\hline Syzygium jambos (L.) Alston & Myrtaceae \\
\hline Syzygium salicifolium (Wight) J.Graham & Myrtaceae \\
\hline Nelumbo nucifera Gaertn. & Nelumbonaceae \\
\hline Boerhavia diffusa $\mathrm{L}$. & Nyctaginaceae \\
\hline Mirabilis jalapa L. & Nyctaginaceae \\
\hline Pisonia aculeata L. & Nyctaginaceae \\
\hline Gomphia serrata (Gaertn.) Kanis & Ochnaceae \\
\hline Ochna obtusata DC. & Ochnaceae \\
\hline Anacolosa crassipes (Kurz) Kurz & Olacaceae \\
\hline Olax acuminata Wall. ex Benth. & Olacaceae \\
\hline Olax scandens Roxb. & Olacaceae \\
\hline
\end{tabular}

\begin{tabular}{|c|c|}
\hline Ximenia americana L. & Olacaceae \\
\hline Chionanthus zeylanicus L. & Oleaceae \\
\hline Fraxinus micrantha Lingelsh. & Oleaceae \\
\hline Jasminum angustifolium (L.) Willd. & Oleaceae \\
\hline Jasminum arborescens Roxb. & Oleaceae \\
\hline Jasminum auriculatum Vahl & Oleaceae \\
\hline Jasminum grandiflorum $\mathrm{L}$. & Oleaceae \\
\hline Jasminum humile L. & Oleaceae \\
\hline Jasminum lanceolarium Roxb. & Oleaceae \\
\hline Jasminum multiflorum (Burm.f.) Andrews & Oleaceae \\
\hline Myxopyrum smilacifolium (Wall.) Blume & Oleaceae \\
\hline Nyctanthes arbor-tristis L. & Oleaceae \\
\hline Olea dioica Roxb. & Oleaceae \\
\hline Schrebera swietenioides Roxb. & Oleaceae \\
\hline Ludwigia adscendens (L.) H.Hara & Onagraceae \\
\hline Ludwigia hyssopifolia (G.Don) Exell & Onagraceae \\
\hline Cansjera rheedei J.F.Gmel. & Opiliaceae \\
\hline Crepidium acuminatum (D.Don) Szlach. & Orchidaceae \\
\hline Habenaria digitata Lindl. & Orchidaceae \\
\hline Habenaria furcifera Lindl. & Orchidaceae \\
\hline Habenaria marginata Colebr. & Orchidaceae \\
\hline Habenaria grandifloriformis Blatt. \& McCann & Orchidaceae \\
\hline Vanda tessellata (Roxb.) Hook. ex G.Don & Orchidaceae \\
\hline Vanda testacea (Lindl.) Rchb.f. & Orchidaceae \\
\hline
\end{tabular}




\section{Ethnobotany Research and Applications}

\begin{tabular}{|c|c|}
\hline Striga angustifolia (D. Don) C.J. Saldanha & Orobanchaceae \\
\hline Striga asiatica (L.) Kuntze & Orobanchaceae \\
\hline Biophytum reinwardtii (Zucc.) Klotzsch & Oxalidaceae \\
\hline Biophytum sensitivum (L.) DC. & Oxalidaceae \\
\hline Oxalis corniculata L. & Oxalidaceae \\
\hline Oxalis latifolia Kunth & Oxalidaceae \\
\hline Pandanus odorifer (Forssk.) Kuntze & Pandanaceae \\
\hline Argemone mexicana $\mathrm{L}$. & Papaveraceae \\
\hline Meconopsis aculeata Royle & Papaveraceae \\
\hline Passiflora foetida L. & Passifloraceae \\
\hline Pedalium murex $\mathrm{L}$. & Pedaliaceae \\
\hline Eurya acuminata DC. & Pentaphylacaceae \\
\hline Eurya japonica Thunb. & Pentaphylacaceae \\
\hline Antidesma acidum Retz. & Phyllanthaceae \\
\hline $\begin{array}{l}\text { Aporosa octandra (Buch.-Ham. ex D.Don) } \\
\text { Vickery }\end{array}$ & Phyllanthaceae \\
\hline Bischofia javanica Blume & Phyllanthaceae \\
\hline Breynia retusa (Dennst.) Alston & Phyllanthaceae \\
\hline Breynia vitis-idaea (Burm.f.) C.E.C.Fisch. & Phyllanthaceae \\
\hline Bridelia retusa (L.) A.Juss. & Phyllanthaceae \\
\hline Bridelia stipularis (L.) Blume & Phyllanthaceae \\
\hline Bridelia tomentosa Blume & Phyllanthaceae \\
\hline Cleistanthus collinus (Roxb.) Benth. ex Hook.f. & Phyllanthaceae \\
\hline Embelia ribes Burm.f. & Phyllanthaceae \\
\hline
\end{tabular}

\begin{tabular}{|c|c|}
\hline $\begin{array}{l}\text { Embelia tsjeriam-cottam (Roem. \& Schult.) } \\
\text { A.DC. }\end{array}$ & Phyllanthaceae \\
\hline Flueggea leucopyrus Willd. & Phyllanthaceae \\
\hline Flueggea virosa (Roxb. ex Willd.) Royle & Phyllanthaceae \\
\hline Glochidion ellipticum Wight & Phyllanthaceae \\
\hline Glochidion heyneanum (Wight \& Arn.) Wight & Phyllanthaceae \\
\hline Glochidion lanceolarium (Roxb.) Voigt & Phyllanthaceae \\
\hline Phyllanthus amarus Schumach. \& Thonn. & Phyllanthaceae \\
\hline Phyllanthus debilis Klein ex Willd. & Phyllanthaceae \\
\hline Phyllanthus emblica L. & Phyllanthaceae \\
\hline Phyllanthus fraternus G.L.Webster & Phyllanthaceae \\
\hline Phyllanthus maderaspatensis $\mathrm{L}$. & Phyllanthaceae \\
\hline Phyllanthus niruri L. & Phyllanthaceae \\
\hline Phyllanthus parvifolius Buch.-Ham. ex D.Don & Phyllanthaceae \\
\hline Phyllanthus polyphyllus Willd. & Phyllanthaceae \\
\hline Phyllanthus reticulatus Poir. & Phyllanthaceae \\
\hline Phyllanthus urinaria L. & Phyllanthaceae \\
\hline Phyllanthus virgatus G.Forst. & Phyllanthaceae \\
\hline Peperomia tetraphylla (G.Forst.) Hook. \& Arn. & Piperaceae \\
\hline Piper attenuatum Buch.-Ham. ex Miq. & Piperaceae \\
\hline Piper betle L. & Piperaceae \\
\hline Piper griffithii C.DC. & Piperaceae \\
\hline Piper longum L. & Piperaceae \\
\hline Piper nigrum L. & Piperaceae \\
\hline
\end{tabular}




\section{Ethnobotany Research and Applications}

\begin{tabular}{|c|c|}
\hline Pittosporum wightii A.K.Mukh. & Pittosporaceae \\
\hline Bacopa monnieri (L.) Wettst. & Plantaginaceae \\
\hline Limnophila indica (L.) Druce & Plantaginaceae \\
\hline $\begin{array}{l}\text { Lindenbergia grandiflora (Buch.-Ham. ex D. Don) } \\
\text { Benth. }\end{array}$ & Plantaginaceae \\
\hline Picrorhiza kurrooa Royle & Plantaginaceae \\
\hline Plantago asiatica subsp. erosa (Wall.) Z.Yu Li & Plantaginaceae \\
\hline Scoparia dulcis L. & Plantaginaceae \\
\hline Plumbago zeylanica L. & Plumbaginaceae \\
\hline Apluda mutica L. & Poaceae \\
\hline Aristida adscensionis L. & Poaceae \\
\hline Bambusa bambos (L.) Voss & Poaceae \\
\hline Chloris barbata Sw. & Poaceae \\
\hline Chrysopogon aciculatus (Retz.) Trin. & Poaceae \\
\hline Chrysopogon zizanioides (L.) Roberty & Poaceae \\
\hline Coix lacryma-jobi L. & Poaceae \\
\hline Cymbopogon citratus (DC.) Stapf & Poaceae \\
\hline $\begin{array}{l}\text { Cymbopogon flexuosus (Nees ex Steud.) } \\
\text { W.Watson }\end{array}$ & Poaceae \\
\hline Cynodon dactylon (L.) Pers. & Poaceae \\
\hline Dactyloctenium aegyptium (L.) Willd. & Poaceae \\
\hline Dendrocalamus strictus (Roxb.) Nees & Poaceae \\
\hline Desmostachya bipinnata (L.) Stapf & Poaceae \\
\hline Echinochloa crus-galli (L.) P.Beauv. & Poaceae \\
\hline Eleusine indica (L.) Gaertn. & Poaceae \\
\hline
\end{tabular}

\begin{tabular}{ll}
\hline Eragrostis nigra Nees ex Steud. & Poaceae \\
Eulaliopsis binata (Retz.) C.E.Hubb. & Poaceae \\
Heteropogon contortus (L.) P.Beauv. ex Roem. \& & Poaceae \\
Schult. & \\
Imperata cylindrica (L.) Raeusch. & Poaceae \\
Oryza sativa L. & Poaceae \\
Saccharum bengalense Retz. & Poaceae \\
Saccharum officinarum L. & Poaceae \\
Setaria macrostachya Kunth & Poaceae \\
Sporobolus diandrus (Retz.) P.Beauv. & Poaceae \\
Themeda quadrivalvis (L.) Kuntze & Poaceae \\
Polygala arvensis Willd. & Polygalaceae \\
Polygala chinensis L. & Polygalaceae \\
Polygala elongata Klein ex Willd. & Polygalaceae \\
Fagopyrum acutatum (Lehm.) Mansf. ex & Polygonaceae \\
K.Hammer & Polygonaceae \\
Fagopyrum esculentum Moench & \\
Persicaria amplexicaulis (D.Don) Ronse Decr. & Polygonaceae \\
H.Grosicaria capitata (Buch.-Ham. ex D.Don) & \\
Persicaria chinensis (L.) H. Gross & Polygonaceae \\
Persicaria glabra (Willd.) M.Gómez \\
Persicaria hydropiper (L.) Delarbre \\
Persicaria orientalis (L.) Spach
\end{tabular}




\section{Ethnobotany Research and Applications}

\begin{tabular}{|c|c|}
\hline Rumex hastatus D. Don & Polygonaceae \\
\hline Rumex nepalensis Spreng. & Polygonaceae \\
\hline Rumex vesicarius $\mathrm{L}$. & Polygonaceae \\
\hline Anagallis arvensis $\mathrm{L}$. & Primulaceae \\
\hline Ardisia paniculata Roxb. & Primulaceae \\
\hline Maesa indica (Roxb.) A. DC. & Primulaceae \\
\hline Myrsine africana $\mathrm{L}$. & Primulaceae \\
\hline Myrsine semiserrata Wall. & Primulaceae \\
\hline Helicia excelsa (Roxb.) Blume & Proteaceae \\
\hline Drypetes sepiaria (Wight \& Arn.) Pax \& K.Hoffm. & Putranjivaceae \\
\hline Putranjiva roxburghii Wall. & Putranjivaceae \\
\hline Aconitum heterophylloides (Brühl) Stapf & Ranunculaceae \\
\hline Aconitum heterophyllum Wall. ex Royle & Ranunculaceae \\
\hline Aconitum villosum Rchb. & Ranunculaceae \\
\hline Anemone obtusiloba D.Don & Ranunculaceae \\
\hline Aquilegia fragrans Benth. & Ranunculaceae \\
\hline Clematis buchananiana DC. & Ranunculaceae \\
\hline Clematis gouriana Roxb. ex DC. & Ranunculaceae \\
\hline Clematis heynei M.A.Rau \& al. & Ranunculaceae \\
\hline Nigella sativa L. & Ranunculaceae \\
\hline Ranunculus arvensis $\mathrm{L}$. & Ranunculaceae \\
\hline Ranunculus sceleratus L. & Ranunculaceae \\
\hline Thalictrum foliolosum DC. & Ranunculaceae \\
\hline Gouania tiliifolia Lam. & Rhamnaceae \\
\hline
\end{tabular}

\begin{tabular}{|c|c|}
\hline Scutia myrtina (Burm.f.) Kurz & Rhamnaceae \\
\hline Ventilago denticulata Willd. & Rhamnaceae \\
\hline Ventilago maderaspatana Gaertn. & Rhamnaceae \\
\hline Ziziphus glabrata B.Heyne ex Roth & Rhamnaceae \\
\hline Ziziphus jujuba Mill. & Rhamnaceae \\
\hline Ziziphus nummularia (Burm.f.) Wight \& Arn. & Rhamnaceae \\
\hline Ziziphus oenopolia (L.) Mill. & Rhamnaceae \\
\hline Ziziphus rugosa Lam. & Rhamnaceae \\
\hline Ziziphus xylopyrus (Retz.) Willd. & Rhamnaceae \\
\hline Carallia brachiata (Lour.) Merr. & Rhizophoraceae \\
\hline Agrimonia pilosa Ledeb. & Rosaceae \\
\hline Cotoneaster affinis Lindl. & Rosaceae \\
\hline Cotoneaster microphyllus Wall. ex Lindl. & Rosaceae \\
\hline Docynia indica (Wall.) Decne. & Rosaceae \\
\hline Duchesnea indica (Jacks.) Focke & Rosaceae \\
\hline Geum elatum Wall. ex Hook.f. & Rosaceae \\
\hline Malus domestica Borkh. & Rosaceae \\
\hline Potentilla indica (Jacks.) Th.Wolf & Rosaceae \\
\hline Prinsepia utilis Royle & Rosaceae \\
\hline Prunus campanulata Maxim. & Rosaceae \\
\hline Prunus nepalensis Ser. & Rosaceae \\
\hline Pyracantha crenulata (Roxb. ex D.Don) M.Roem. & Rosaceae \\
\hline Pyrus pashia Buch.-Ham. ex D.Don & Rosaceae \\
\hline Rubus foliosus Weihe & Rosaceae \\
\hline
\end{tabular}




\section{Ethnobotany Research and Applications}

\begin{tabular}{ll}
\hline Rubus x nobilis hort. angl. ex Regel & Rosaceae \\
Rubus biflorus Buch.-Ham. ex Sm. & Rosaceae \\
Rubus buergeri Miq. & Rosaceae \\
Rubus ellipticus Sm. & Rosaceae \\
Rubus khasianus Cardot & Rosaceae \\
Rubus niveus Thunb. & Rosaceae \\
Benkara malabarica (Lam.) Tirveng. & Rubiaceae \\
Canthium coromandelicum (Burm.f.) Alston & Rubiaceae \\
Catunaregam spinosa (Thunb.) Tirveng. & Rubiaceae \\
Catunaregam spinosa (Thunb.) Tirveng. & Rubiaceae \\
Ceriscoides campanulata (Roxb.) Tirveng. & Rubiaceae \\
Chassalia curviflora (Wall.) Thwaites & Rubiaceae \\
Coffea benghalensis B.Heyne ex Schult. & Rubiaceae \\
Galium asperifolium Wall. & Rubiaceae \\
Galium elegans Wall. ex Roxb. & Rubiaceae \\
Galium rotundifolium L. & Rubiaceae \\
Gardenia gummifera L.f. & Rubiaceae \\
Gardenia latifolia Aiton & Rubiaceae \\
Gardenia resinifera Roth & Rubiaceae \\
Geophila repens (L.) I.M.Johnst. & Rubiaceae \\
Haldina cordifolia (Roxb.) Ridsdale & Rubiaceae \\
Hedyotis scandens Roxb. & Rubiaceae \\
Himalrandia tetrasperma (Wall. ex Roxb.) & Rubiaceae \\
T.Yamaz. & \\
\hline
\end{tabular}

\begin{tabular}{ll}
\hline Houstonia purpurea L. & Rubiaceae \\
Ixora coccinea L. & Rubiaceae \\
Ixora elongata B.Heyne ex G.Don & Rubiaceae \\
Ixora malabarica (Dennst.) Mabb. & Rubiaceae \\
Ixora parviflora Lam. & Rubiaceae \\
Ixora pavetta Andr. & Rubiaceae \\
Ixora thwaitesii Hook.f. & Rubiaceae \\
Meyna laxiflora Robyns & Rubiaceae \\
Meyna spinosa Roxb. ex Link & Rubiaceae \\
Mitragyna parvifolia var. microphylla (Kurz) & Rubiaceae \\
Ridsdale & \\
Morinda citrifolia L. & Rubiaceae \\
Morinda coreia Buch.-Ham. & Rubiaceae \\
Morinda umbellata L. & Rubiaceae \\
Mussaenda frondosa L. & Rubiaceae \\
Neolamarckia cadamba (Roxb.) Bosser & Rubiaceae \\
Neonauclea purpurea (Roxb.) Merr. & Rubiaceae \\
Oldenlandia corymbosa L. & Rubiaceae \\
Oldenlandia diffusa (Willd.) Roxb. & Rubiaceae \\
Oldenlandia umbellata L. & Rubiaceae \\
Ophiorrhiza mungos L. & Rubiaceae \\
Oxyceros longiflorus (Lam.) T.Yamaz. & Rubiaceae \\
Paederia foetida L. & Rubiaceae \\
Pavetta indica L. & Rubiaceae \\
\hline & \\
\hline
\end{tabular}




\section{Ethnobotany Research and Applications}

\begin{tabular}{|c|c|}
\hline Pavetta tomentosa Roxb. ex Sm. & Rubiaceae \\
\hline Psydrax dicoccos Gaertn. & Rubiaceae \\
\hline Richardia scabra L. & Rubiaceae \\
\hline Rubia cordifolia L. & Rubiaceae \\
\hline Rubia manjith Roxb. ex Fleming & Rubiaceae \\
\hline Saprosma ternatum (Wall.) Hook.f. & Rubiaceae \\
\hline Spermacoce alata Aubl. & Rubiaceae \\
\hline Spermacoce articularis L.f. & Rubiaceae \\
\hline Spermacoce hispida L. & Rubiaceae \\
\hline Spermadictyon suaveolens Roxb. & Rubiaceae \\
\hline Tamilnadia uliginosa (Retz.) Tirveng. \& Sastre & Rubiaceae \\
\hline Tarenna asiatica (L.) Kuntze ex K.Schum. & Rubiaceae \\
\hline $\begin{array}{l}\text { Wendlandia heynei (Schult.) Santapau \& } \\
\text { Merchant }\end{array}$ & Rubiaceae \\
\hline Wendlandia tinctoria (Roxb.) DC. & Rubiaceae \\
\hline Acronychia pedunculata (L.) Miq. & Rutaceae \\
\hline Aegle marmelos (L.) Corrêa & Rutaceae \\
\hline Atalantia monophylla DC. & Rutaceae \\
\hline Atalantia racemosa Wight ex Hook. & Rutaceae \\
\hline $\begin{array}{l}\text { Boenninghausenia albiflora (Hook.) Rchb. ex } \\
\text { Meisn. }\end{array}$ & Rutaceae \\
\hline Chloroxylon swietenia DC. & Rutaceae \\
\hline Citrus aurantiifolia (Christm.) Swingle & Rutaceae \\
\hline Citrus latipes (Swingle) Yu.Tanaka & Rutaceae \\
\hline Citrus limon (L.) Osbeck & Rutaceae \\
\hline
\end{tabular}

\begin{tabular}{ll}
\hline Citrus medica L. & Rutaceae \\
Clausena dentata (Willd.) Roem. & Rutaceae \\
Clausena excavata Burm.f. & Rutaceae \\
Glycosmis mauritiana (Lam.) Tanaka & Rutaceae \\
Glycosmis pentaphylla (Retz.) DC. & Rutaceae \\
Hesperethusa crenulata (Roxb.) M. Roem. & Rutaceae \\
Limonia acidissima Groff & Rutaceae \\
Micromelum pubescens Blume & Rutaceae \\
Murraya koenigii (L.) Spreng. & Rutaceae \\
Murraya paniculata (L.) Jack & Rutaceae \\
Naringi alata (Wall. ex Wight \& Arn.) J.L.Ellis & Rutaceae \\
Pamburus missionis (Wight) Swingle & Rutaceae \\
Pleiospermium alatum (Wight \& Arn.) Swingle & Rutaceae \\
Ruta graveolens L. & Rutaceae \\
Skimmia laureola Franch. & Rutaceae \\
Toddalia asiatica (L.) Lam. & Rutaceae \\
Zanthoxylum armatum DC. & Rutaceae \\
Zanthoxylum khasianum Hook. f. & Rutaceae \\
Zanthoxylum limonella (Dennst.) Alston & Rutaceae \\
Zanthoxylum oxyphyllum Edgew. & Rutaceae \\
Zanthoxylum rhetsa DC. & Rutaceae \\
Casearia vareca Roxb. & Salicaceae \\
Flacourtia indica (Burm.f.) Merr. & Salicaceae \\
Flacourtia jangomas (Lour.) Raeusch. & Salicaceae \\
\hline & \\
\hline
\end{tabular}




\section{Ethnobotany Research and Applications}

\begin{tabular}{|c|c|}
\hline Flacourtia montana J.Graham & Salicaceae \\
\hline Populus ciliata Wall. ex Royle & Salicaceae \\
\hline Salix tetrasperma Roxb. & Salicaceae \\
\hline Xylosma longifolia Clos & Salicaceae \\
\hline Azima tetracantha Lam. & Salvadoraceae \\
\hline Salvadora oleoides Decne. & Salvadoraceae \\
\hline Salvadora persica L. & Salvadoraceae \\
\hline Santalum album $\mathrm{L}$. & Santalaceae \\
\hline Viscum angulatum B.Heyne ex DC. & Santalaceae \\
\hline Acer oblongum Wall. ex DC. & Sapindaceae \\
\hline Aesculus assamica Griff. & Sapindaceae \\
\hline Aesculus indica (Wall. ex Cambess.) Hook. & Sapindaceae \\
\hline Allophylus cobbe (L.) Raeusch. & Sapindaceae \\
\hline Allophylus serratus (Hiern) Kurz & Sapindaceae \\
\hline Cardiospermum corindum L. & Sapindaceae \\
\hline Cardiospermum halicacabum L. & Sapindaceae \\
\hline Dodonaea viscosa (L.) Jacq. & Sapindaceae \\
\hline Lepisanthes tetraphylla Radlk. & Sapindaceae \\
\hline Sapindus attenuatus Wall. & Sapindaceae \\
\hline Sapindus emarginatus Vahl & Sapindaceae \\
\hline Sapindus laurifolius Vahl & Sapindaceae \\
\hline Sapindus mukorossi Gaertn. & Sapindaceae \\
\hline Schleichera oleosa (Lour.) Merr. & Sapindaceae \\
\hline Madhuca longifolia (J.Koenig ex L.) J.F.Macbr. & Sapotaceae \\
\hline
\end{tabular}

\begin{tabular}{|c|c|}
\hline Madhuca neriifolia (Moon) H.J.Lam & Sapotaceae \\
\hline Mimusops elengi $\mathrm{L}$. & Sapotaceae \\
\hline Houttuynia cordata Thunb. & Saururaceae \\
\hline Bergenia ciliata (Haw.) Sternb. & Saxifragaceae \\
\hline Verbascum thapsus L. & Scrophulariaceae \\
\hline Ailanthus excelsa Roxb. & Simaroubaceae \\
\hline Brucea javanica (L.) Merr. & Simaroubaceae \\
\hline Picrasma javanica Blume & Simaroubaceae \\
\hline Smilax aspera L. & Smilacaceae \\
\hline Smilax ovalifolia Roxb. ex D.Don & Smilacaceae \\
\hline Smilax perfoliata Lour. & Smilacaceae \\
\hline Smilax zeylanica L. & Smilacaceae \\
\hline Brugmansia suaveolens (Willd.) Sweet & Solanaceae \\
\hline Capsicum annuum L. & Solanaceae \\
\hline Datura inoxia Mill. & Solanaceae \\
\hline Datura metel L. & Solanaceae \\
\hline Datura stramonium $\mathrm{L}$. & Solanaceae \\
\hline Hyoscyamus niger L. & Solanaceae \\
\hline Nicotiana tabacum L. & Solanaceae \\
\hline Physalis minima L. & Solanaceae \\
\hline Physochlaina praealta (Decne.) Miers & Solanaceae \\
\hline Solanum aculeatissimum Jacq. & Solanaceae \\
\hline Solanum americanum Mill. & Solanaceae \\
\hline Solanum melongena $\mathrm{L}$. & Solanaceae \\
\hline
\end{tabular}




\section{Ethnobotany Research and Applications}

\begin{tabular}{|c|c|}
\hline Solanum surattense Burm.f. & Solanaceae \\
\hline Solanum torvum Sw. & Solanaceae \\
\hline Solanum trilobatum $\mathrm{L}$. & Solanaceae \\
\hline Solanum violaceum Ortega & Solanaceae \\
\hline Solanum virginianum $\mathrm{L}$. & Solanaceae \\
\hline Withania somnifera (L.) Dunal & Solanaceae \\
\hline Gomphandra coriacea Wight & Stemonuraceae \\
\hline Symplocos lucida (Thunb.) Siebold \& Zucc. & Symplocaceae \\
\hline Symplocos racemosa Roxb. & Symplocaceae \\
\hline Symplocos ramosissima Wall. ex G. Don & Symplocaceae \\
\hline Camellia kissii Wall. & Theaceae \\
\hline Schima khasiana Dyer & Theaceae \\
\hline Schima wallichii Choisy & Theaceae \\
\hline Aquilaria agallocha Roxb. & Thymelaeaceae \\
\hline Daphne mucronata Royle & Thymelaeaceae \\
\hline Daphne papyracea Wall. ex G. Don & Thymelaeaceae \\
\hline Typha domingensis Pers. & Typhaceae \\
\hline Holoptelea integrifolia Planch. & Ulmaceae \\
\hline Boehmeria macrophylla Hornem. & Urticaceae \\
\hline Boehmeria rugulosa Wedd. & Urticaceae \\
\hline Girardinia diversifolia (Link) Friis & Urticaceae \\
\hline Pouzolzia hirta Blume ex Hassk. & Urticaceae \\
\hline $\begin{array}{l}\text { Pouzolzia pentandra var. wightii (Benn. \& Br.) } \\
\text { Friis \& Wilmot-Dear }\end{array}$ & Urticaceae \\
\hline
\end{tabular}

\begin{tabular}{|c|c|}
\hline Pouzolzia zeylanica (L.) Benn. & Urticaceae \\
\hline Urtica dioica L. & Urticaceae \\
\hline Duranta erecta L. & Verbenaceae \\
\hline Lantana camara L. & Verbenaceae \\
\hline Lantana indica Roxb. & Verbenaceae \\
\hline Lippia javanica (Burm.f.) Spreng. & Verbenaceae \\
\hline Phyla nodiflora (L.) Greene & Verbenaceae \\
\hline Stachytarpheta jamaicensis (L.) Vahl & Verbenaceae \\
\hline Hybanthus enneaspermus (L.) F.Muell. & Violaceae \\
\hline Hybanthus linearifolius (Vahl) Urb. & Violaceae \\
\hline Viola canescens Wall. & Violaceae \\
\hline Viola diffusa Ging. & Violaceae \\
\hline Viola pilosa Blume & Violaceae \\
\hline Ampelocissus indica (L.) Planch. & Vitaceae \\
\hline Ampelocissus latifolia (Roxb.) Planch. & Vitaceae \\
\hline $\begin{array}{l}\text { Ampelocissus tomentosa (B.Heyne \& Roth) } \\
\text { Planch. }\end{array}$ & Vitaceae \\
\hline Cayratia pedata (Lam.) Gagnep. & Vitaceae \\
\hline Cayratia trifolia (L.) Domin & Vitaceae \\
\hline Cissus adnata Roxb. & Vitaceae \\
\hline Cissus javana DC. & Vitaceae \\
\hline Cissus quadrangularis L. & Vitaceae \\
\hline Cissus verticillata (L.) Nicolson \& C.E.Jarvis & Vitaceae \\
\hline Cissus vitiginea $\mathrm{L}$. & Vitaceae \\
\hline
\end{tabular}




\section{Ethnobotany Research and Applications}

\begin{tabular}{|c|c|}
\hline Cissus woodrowii (Stapf ex Cooke) Santapau & Vitaceae \\
\hline Leea asiatica (L.) Ridsdale & Vitaceae \\
\hline Leea indica (Burm. f.) Merr. & Vitaceae \\
\hline Leea macrophylla Roxb. ex Hornem. & Vitaceae \\
\hline Tetrastigma leucostaphylum (Dennst.) Alston & Vitaceae \\
\hline Aloe vera (L.) Burm.f. & Xanthorrhoeaceae \\
\hline Alpinia galanga (L.) Willd. & Zingiberaceae \\
\hline Curcuma amada Roxb. & Zingiberaceae \\
\hline Curcuma angustifolia Roxb. & Zingiberaceae \\
\hline Curcuma aromatica Salisb. & Zingiberaceae \\
\hline Curcuma caesia Roxb. & Zingiberaceae \\
\hline Curcuma caulina J.Graham & Zingiberaceae \\
\hline Curcuma longa $\mathrm{L}$. & Zingiberaceae \\
\hline Kaempferia galanga L. & Zingiberaceae \\
\hline Curcuma pseudomontana J.Graham & Zingiberaceae \\
\hline Elettaria cardamomum (L.) Maton & Zingiberaceae \\
\hline Globba marantina L. & Zingiberaceae \\
\hline Hedychium spicatum Sm. & Zingiberaceae \\
\hline Zingiber capitatum Roxb. & Zingiberaceae \\
\hline Zingiber montanum (J.Koenig) Link ex A.Dietr. & Zingiberaceae \\
\hline Zingiber neesanum (J.Graham) & Zingiberaceae \\
\hline Zingiber nimmonii (J.Graham) Dalzell & Zingiberaceae \\
\hline Zingiber officinale Roscoe & Zingiberaceae \\
\hline Zingiber roseum (Roxb.) Roscoe & Zingiberaceae \\
\hline
\end{tabular}

\begin{tabular}{ll}
\hline Balanites aegyptiaca (L.) Delile & Zygophyllaceae \\
Tribulus pentandrus Forssk. & Zygophyllaceae \\
Tribulus terrestris L. & Zygophyllaceae
\end{tabular}


Appendix 2. Representation of plant families against seven prevalent disease categories as recorded from sacred grove studies

\begin{tabular}{|c|c|c|c|c|c|}
\hline Disease Category & $\begin{array}{l}\text { Families } \\
\text { recorded }\end{array}$ & $\begin{array}{l}\text { Species } \\
\text { recorded }\end{array}$ & $\begin{array}{l}50 \% \text { of total species (no. } \\
\text { of families) }\end{array}$ & $\begin{array}{l}75 \% \text { of total species } \\
\text { (no. of families) }\end{array}$ & Top three families \\
\hline $\begin{array}{l}\text { Diseases related to the } \\
\text { digestive system }\end{array}$ & 64 & 170 & $85(11)$ & $127(26)$ & Leguminosae, Apocynaceae, Compositae \\
\hline $\begin{array}{l}\text { Diseases related to the } \\
\text { infections and parasitic } \\
\text { attacks }\end{array}$ & 96 & 366 & $183(11)$ & $274(31)$ & Leguminosae, Malvaceae, Compositae \\
\hline $\begin{array}{l}\text { Diseases related to the } \\
\text { skin and sub-cutaneous } \\
\text { tissues }\end{array}$ & 68 & 153 & $76(12)$ & $114(29)$ & Leguminosae, Compositae, Lamiaceae \\
\hline General health problem & 100 & 358 & $179(13)$ & $268(35)$ & Leguminosae, Compositae, Apocynaceae \\
\hline $\begin{array}{l}\text { Diseases related to the } \\
\text { respiratory system }\end{array}$ & 80 & 240 & $120(11)$ & $180(29)$ & Leguminosae, Lamiaceae, Compositae \\
\hline $\begin{array}{l}\text { Diseases related to the } \\
\text { genito-urinary system }\end{array}$ & 45 & 100 & $50(9)$ & $75(20)$ & Leguminosae, Malvaceae, Compositae \\
\hline
\end{tabular}

